by Rodolfo Coccioni ${ }^{1 *}$, Alessandro Montanari ${ }^{2}$, David Bice $^{3}$, Henk Brinkhuis $^{4}$, Alain Deino $^{5}$,

Fabrizio Frontalini ${ }^{1}$, Fabrizio Lirer ${ }^{6}$, Patrizia Maiorano ${ }^{7}$, Simonetta Monechi ${ }^{8}$, Jörg Pross ${ }^{9}$, Pierre Rochette $^{10}$, Leonardo Sagnotti ${ }^{11}$, Marianna Sideri ${ }^{1}$, Mario Sprovieri ${ }^{12}$, Fabio Tateo ${ }^{13}$, Yannick

Touchard ${ }^{10}$, Stefaan Van Simaeys ${ }^{14}$, and Graham L. Williams ${ }^{15}$

\title{
The Global Stratotype Section and Point (GSSP) for the base of the Chattian Stage (Paleogene System, Oligocene Series) at Monte Cagnero, Italy
}

\author{
${ }^{1}$ Dipartimento di Scienze Pure e Applicate (DiSPeA) dell’Università degli Studi “Carlo Bo," Campus Scientifico, Località Crocicchia, 61029, \\ Urbino, Italy; *Corresponding author, E-mail: rodolfo.coccioni@uniurb.it \\ ${ }^{2}$ Osservatorio Geologico di Coldigioco, 62020 Frontale di Apiro, Italy \\ ${ }^{3}$ Department of Geosciences, the Pennsylvania State University, University Park, Pennsylvania 16802, USA \\ ${ }^{4}$ Laboratory of Palaeobotany and Palynology, Utrecht University, Budapestlaan 4, 3584 CD Utrecht, The Netherlands \\ ${ }^{5}$ Berkeley Geochronology Center, 2453 Ridge Road, Berkeley, California 94709, USA \\ ${ }^{6}$ Istituto per l'Ambiente Marino Costiero (IAMC-CNR), Calata Porta di Massa, Interno Porto di Napoli, 80123 Napoli, Italy \\ ${ }^{7}$ Dipartimento di Scienze della Terra e Geoambientali dell'Università degli Studi di Bari, Via Orabona 4, 70125 Bari, Italy \\ ${ }^{8}$ Dipartimento di Scienze della Terra dell'Università degli Studi di Firenze, Via La Pira 4, 50121 Firenze, Italy \\ ${ }^{9}$ Paleoenvironmental Dynamics Group, Institute of Earth Sciences, University of Heidelberg, Im Neuenheimer Feld 234, 69120 Heidelberg, \\ Germany \\ ${ }^{10}$ Université d'Aix Marseille 3, UMR CNRS 6635, CEREGE Europole de l'Arbois BP80 13545 Aix en Provence Cedex 4, France \\ ${ }^{11}$ Istituto Nazionale di Geofisica e Vulcanologia, Via di Vigna Murata 605, 00143 Roma, Italy \\ ${ }^{12}$ Istituto per l'Ambiente Marino Costiero (IAMC-CNR), Via del Mare 3, 91021 Torretta Granitola, Italy \\ ${ }^{13}$ Dipartimento di Geoscienze e Georisorse-CNR, Via Gardenigo 6, 35131 Padova, Italy \\ ${ }^{14}$ Exxon Mobil Upstream Research Company 22777 Springwood Village Pkwy, EMHC S1.2B.315 Houston, TX 77389, USA \\ ${ }^{15}$ Geological Survey of Canada, Bedford Institute of Oceanography, PO Box 1006, Dartmouth, Nova Scotia, B2Y 4A2, Canada
}

(Received: April 11, 2017; Revised accepted: August 24, 2017)

http://dx.doi.org/10.18814/epiiugs/2018/v41i1/018003

The GSSP for the base of the Chattian Stage (Paleogene System, Oligocene Series) is defined at meter level 197 in the Monte Cagnero section, which belongs to the pelagic succession of the Umbria-Marche basin (Urbania, central Italy: $\left.43^{\circ} 38^{\prime} 47.81^{\prime \prime} \mathrm{N}-12^{\circ} 28^{\prime} 03.83^{\prime \prime} E\right)$. This level with an astronomical age of 27.82 Ma coincides with the highest common occurrence of the planktonic foraminifer Chiloguembelina cubensis at the base of planktonic foraminiferal O5 Zone and falls in the upper part of calcareous nannofossil NP24 Zone, in the lower part of dinocyst Dbi Zone, and in the lower Chron C9n. The proposal was approved by the International Subcommission of Paleogene Stratigraphy in July 2015, approved by the International Commission of Stratigraphy in August 2016, and ratified by the International Union of Geological Sciences in September 2016.

\section{Introduction}

The Rupelian and Chattian historical stratotypes were respectively located in northwestern Belgium and northwestern Germany, in the southern part of the North Sea basin (e.g., Berggren, 1971; Hardenbol and Berggren, 1978; Van Simaeys et al., 2004). Chronostratigraphically meaningful calcareous plankton is sparse in the generally marginal marine sedimentary environment of the historical reference sections, paleomagnetic signals are poor, and radiometrically datable volcanic horizons are absent. Therefore, the historical type localities do not represent suitable and continuous sections for the GSSP that comprises the Rupelian/Chattian boundary. Accordingly, a continuous, well-calibrated base Chattian GSSP section offering good correlation potential has to be sought outside the North Sea basin.

In search of a continuous section as GSSP of the Rupelian/Chattian boundary, the Oligocene Integrated Stratigraphy (OLIS) Working Group was formed to provide an integrated stratigraphy of the pelagic Scaglia Cinerea Formation in the Umbria-Marche (U-M) region of central Italy (Coccioni et al., 2008; Pross et al., 2010), which spans the uppermost Eocene through the entire Oligocene. Of the three sections identified and studied to verify regional correlations - the Contessa Barbetti Road (CBR) near Gubbio, and Pieve d'Accinelli (PAC) near Piobbico, and Monte Cagnero (MCA) near Urbania (Coccioni et al., 2008) - the latter was selected to define the basal Chattian Stage GSSP (Fig. 1). 

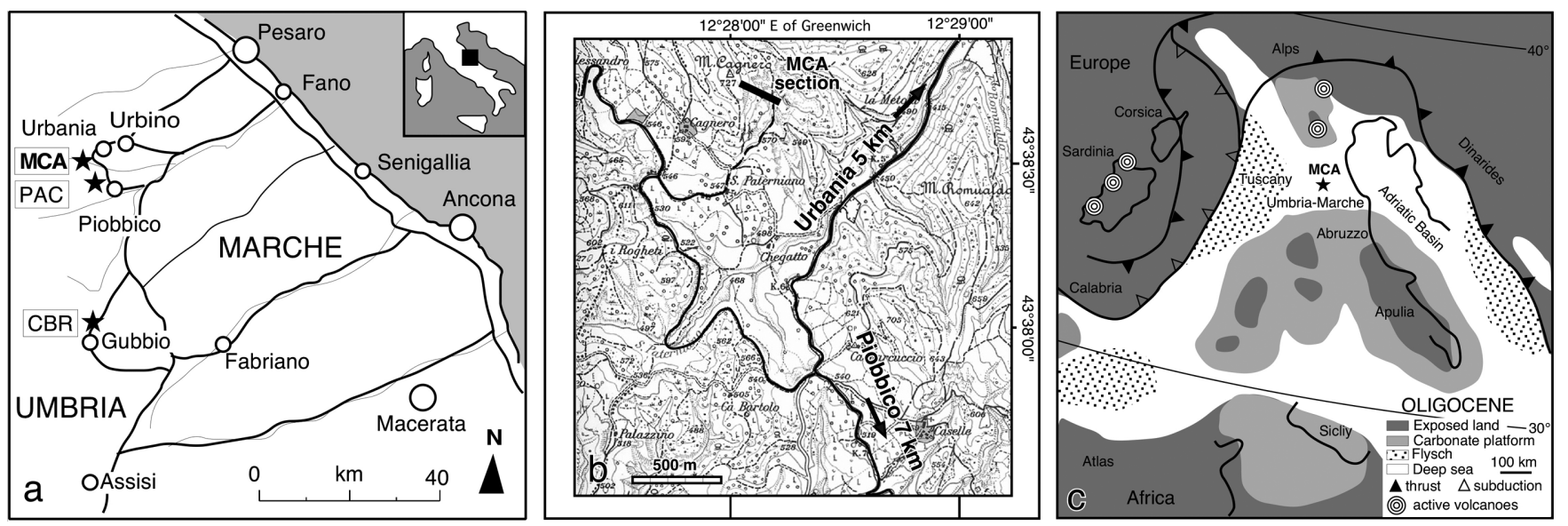

Figure 1. (a) Simplified roadmap of the Umbria-Marche region with the location of the Oligocene sections of Contessa Barbetti Road (CBR), Pieve d'Accinelli (PAC), and Monte Cagnero (MCA); (b) Precise location of the MCA section; (c) Location of the MCA section on an Oligocene paleogeographic map simplified and slightly amended from Dercourt et al. (1993).

\section{Location and Geological Setting}

The 86-m-thick MCA section is located on the southeastern slope of Monte Cagnero (727 m above sea level; coordinates: $43^{\circ} 38^{\prime} 47.81^{\prime \prime} \mathrm{N}-$ $\left.12^{\circ} 28^{\prime} 03.83^{\prime \prime} \mathrm{E}\right)$, a few kilometers to the SW of the town of Urbania (Fig. 1b) (Coccioni et al., 2008).

The MCA section consists of a rhythmic alternation of gray-bluish, pelagic marls, calcareous marls and marly limestones belonging to the Scaglia Cinerea Formation whose carbonate component is mainly made up of planktonic foraminiferal tests and calcareous nannofossils, and the siliciclastic component is represented by terrigenous clay and silt (Fig. 2). The MCA section is free of turbidites and any other manifestation of basinal instability. Rare intercalations of thin, biotiterich volcano-sedimentary horizons are found and provide the means for direct radioisotopic dating of the magnetobiostratigraphy (Coccioni et al., 2008, and references therein) (Fig. 2).

\section{Stratigraphy}

The MCA section as GSSP for the base of the Chattian Stage (Fig. 2 ) is the continuation of the underlying upper Priabonian to middle Rupelian section, whose integrated stratigraphy and astrochronologic calibration were determined by Hyland et al. (2009). However, while working on the Rupelian to Chattian portion of the section, carefully re-checking the stratimetry of Hyland et al. (2009), we found an error of one meter in the measured thickness at about meter level 125, in a stretch of the section that crosses, for a few meters, a dirt road. Consequently, we had to add one meter to the section of Coccioni et al. (2008) (Fig. 2). A stratigraphic synthesis of the GSSP section of MCA is shown in Figure 3, and described in detail below.

\section{Lithostratigraphy}

The rhythmic bedding of the pelagic Scaglia Cinerea Formation is clearly manifested in the well-exposed southeastern slope of Monte Cagnero as a stepped topography, with prominent benches formed by hard limestone layers protruding out of recessive, softer marls (Fig. 4a). These calcareous benches are organized in cycles with a mean wavelength of about $5.6 \mathrm{~m}$, as revealed by a band pass filtered curve obtained from a high-resolution magnetic susceptibility series, where low susceptibility represents calcareous marls and marly limestones, and high susceptibility represents marls with a higher terrigenous (magnetic) content (Fig. 4a). The GSSP for the base of the Chattian Stage is located at the highest common occurrence ( $\mathrm{HCO}$ ) of the planktonic foraminifer Chiloguembelina cubensis, i.e., the O4/O5 planktonic foraminiferal zonal boundary of Wade et al. (2011), at meter level 197, thirty $\mathrm{cm}$ below the base of a prominent calcareous bed within an otherwise recessive, relatively thick marly interval (Figs. 2 and 4b).

\section{Biostratigraphy and Paleodepth}

The pelagic sediments of the MCA section contain abundant calcareous nannofossils and planktonic foraminifera, with common benthic foraminifera and rare ostracods. Palynomorphs are abundant as well. Macrofossils were not found. Ichnofossils are common and mainly represented by Zoophycos and Planolites.

\section{Planktonic foraminifera}

Planktonic foraminiferal analysis is based on 173 samples collected at an average sampling resolution of $50 \mathrm{~cm}$ (Fig. 2) that corresponds to $\sim 37.5 \mathrm{kyr}$ and processed to obtain washed residues greater than $32 \mu \mathrm{m}$ using standard micropaleontological techniques. Planktonic foraminiferal assemblages are rich, diverse, and well preserved throughout the section. The planktonic foraminiferal standard zonation of Wade et al. (2011) was applied, with the taxonomy of Paragloborotalia opima and Paragloborotalia nana assessed following the taxonomic size-based concepts established by Wade et al. (2016). Primary and secondary events were recognized throughout $\mathrm{O} 2$ to $\mathrm{O} 6$ Zones (Figs. 2, 3, and 5; Table 1).

A progressive giantism of $P$. opima with increasing abundance of the larger forms from the lower part of Chron C10n to the lower part of Chron C9n was recognized by Wade et al. (2016) through the midlate Oligocene at Site U1334 (eastern equatorial Pacific Ocean). A 


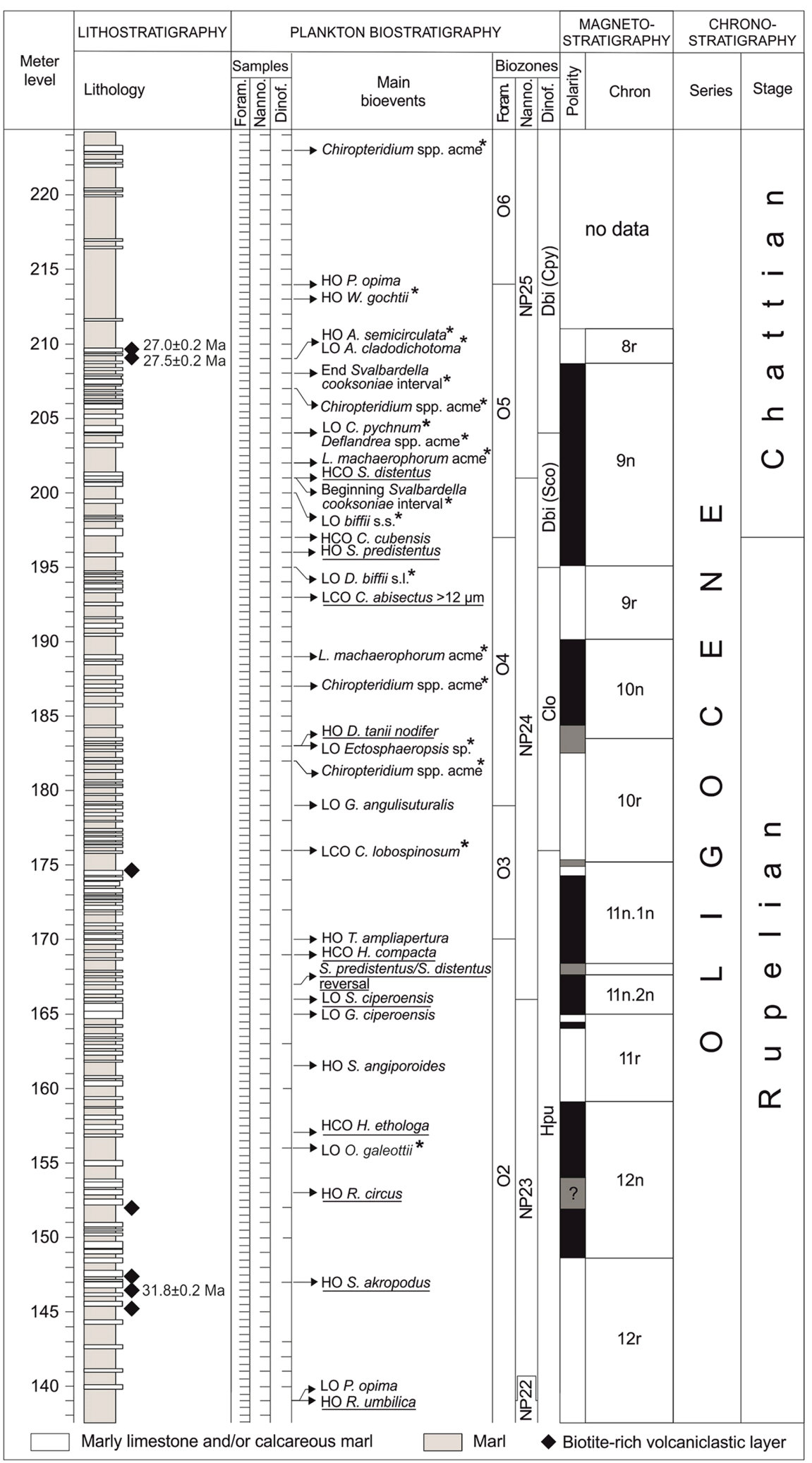

Figure 2. Litho-, magneto-, bio- and chronostratigraphy of the Monte Cagnero (MCA) section (modified after Coccioni et al., 2008; Hyland et al., 2009; Pross et al., 2010, and this work). Underlined - calcareous nannofossil events; asterisk - dinoflagellate cyst events; unmarked-planktonic foraminiferal events. Biozones after Wade et al. (2011) for planktonic foraminifera, Martini (1971) for calcareous nannofossils, and Pross et al. (2010) for dinoflagellate cysts. Ar/Ar ages from volcaniclastic biotite recalculated with the new age of the Fish Canyon Tuff standard by Kuiper et al. (2008). According to our astrochronology, the MCA section spans $\sim 6$ Myr with an average sedimentation rate of $1.45 \mathrm{~cm} / \mathrm{kyr}$. peak size of $680 \mu \mathrm{m}$ is recorded in the lower part of Chron C9n very close ( $\sim 2 \mathrm{~m}$ apart) to the Top occurrence of $C$. cubensis that according to King and Wade (2017) represents the highest (last) occurrence of this species. Following this peak, the maximum size of $P$. opima decreases with its extinction event that marks the base of the late Oligocene Zone O6. Interestingly, a very similar pattern in abundance and size of $P$. opima is recognizable at MCA, with a peak size recorded in the lower part of Chron C9n very close ( 1 m apart) to the HCO of C. cubensis and followed by rare and sporadic occurrences of $P$. opima up to its demise at meter level 214. After that only the smaller $P$. nana forms continue into Zone O6.

The degree of reliability of the $\mathrm{HCO}$ of C. cubensis as the global criterion for the Rupelian/Chattian boundary

The highest occurrence (HO) of C. cubensis has traditionally been used as the criterion for the recognition of the Rupelian/Chattian boundary worldwide and calibrated to the top of Subzone P21a associated in between Chrons C9n and C10n (e.g., Berggren et al., 1995; Luterbacher et al., 2004, and references therein), although sporadic occurrences in reduced numbers of this species have been reported through the upper Oligocene (Hess et al., 1989; Leckie et al., 1993). However, C. cubensis is a small species that may be easily reworked, as argued by Poore et al. (1982) and Poore (1984) for its occasional occurrences within the upper Oligocene.

Van Simaeys et al. (2004) suggested that the $\mathrm{HO}$ of $C$. cubensis was globally diachronous and likely controlled by paleolatitude and paleobiogeography, therefore questioning its validity as a reliable global Rupelian/Chattian boundary criterion.

In view of these problems with the decline in abundance of $C$. cubensis, Berggren and Pearson (2005) used the HCO of this species rather than its HO to mark the Rupelian/Chattian boundary and placed this biohorizon at the boundary between the planktonic foraminiferal Zones $\mathrm{O} 4$ and $\mathrm{O} 5$ corresponding to the boundary between Subzones P21a and P21b of Berggren et al. (1995) and within Chron C10n.

Wade et al. (2007) documented that the HCO of $C$. cubensis is synchronous at a number of Drilling Deep Sea Drilling Project (DSDP) and Ocean Drilling Program (ODP) sites and may be correlated directly or indirectly with Chron 


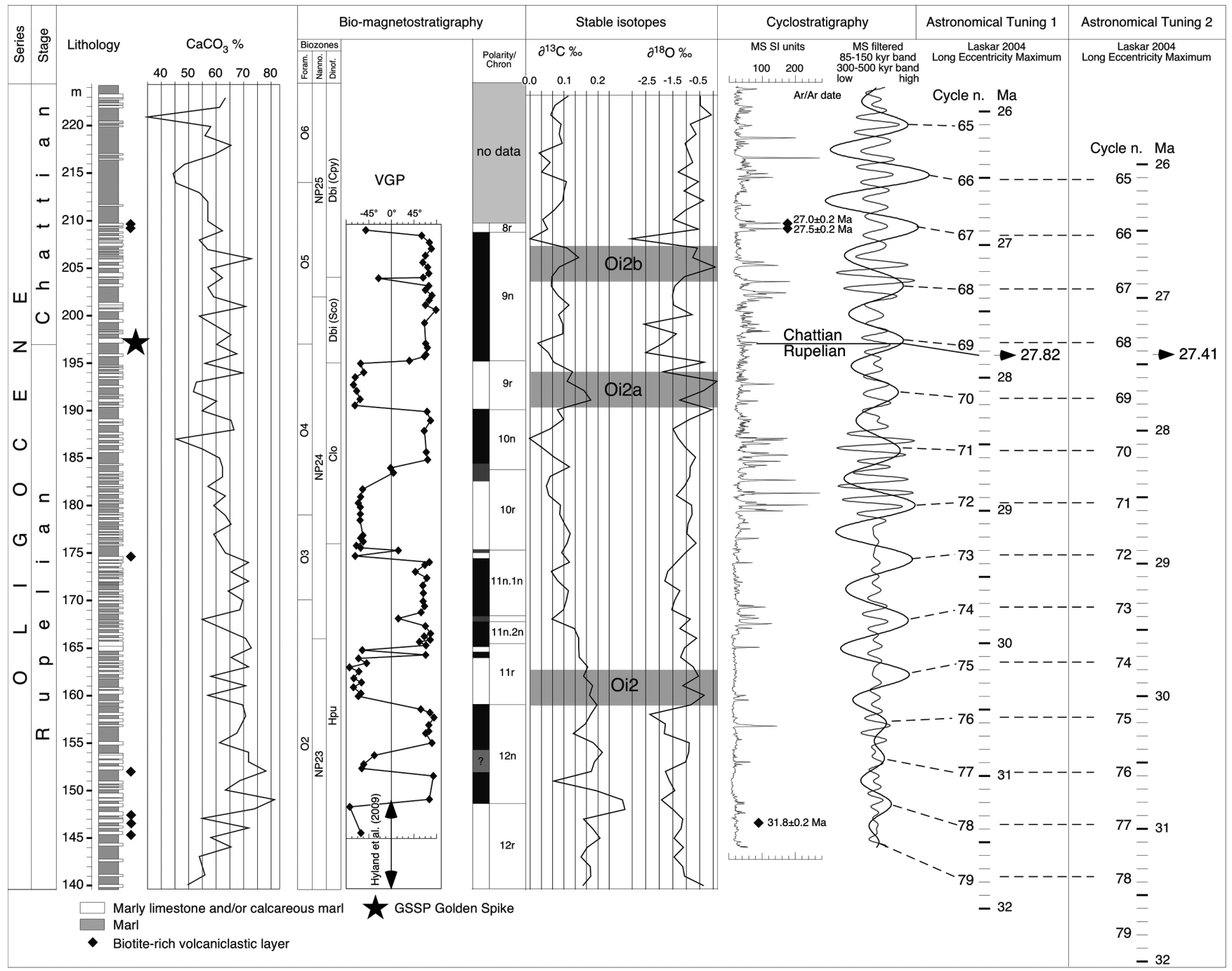

Figure 3. Integrated stratigraphic model of the Monte Cagnero (MCA) section. Litho- and magnetobiostratigraphy, stable isotope stratigraphy, glacial events (Oi2, Oi2a, and Oi2b), and radioisotope geochronology modified after Coccioni et al. (2008). Biozones after Wade et al. (2011) for planktonic foraminifera, Martini (1971) for calcareous nannofossils, and Pross et al. (2010) for dinoflagellate cysts. Astronomical tuning based on the long and short eccentricity cycles of Laskar et al. (2004) is from this work (see text for explanation).
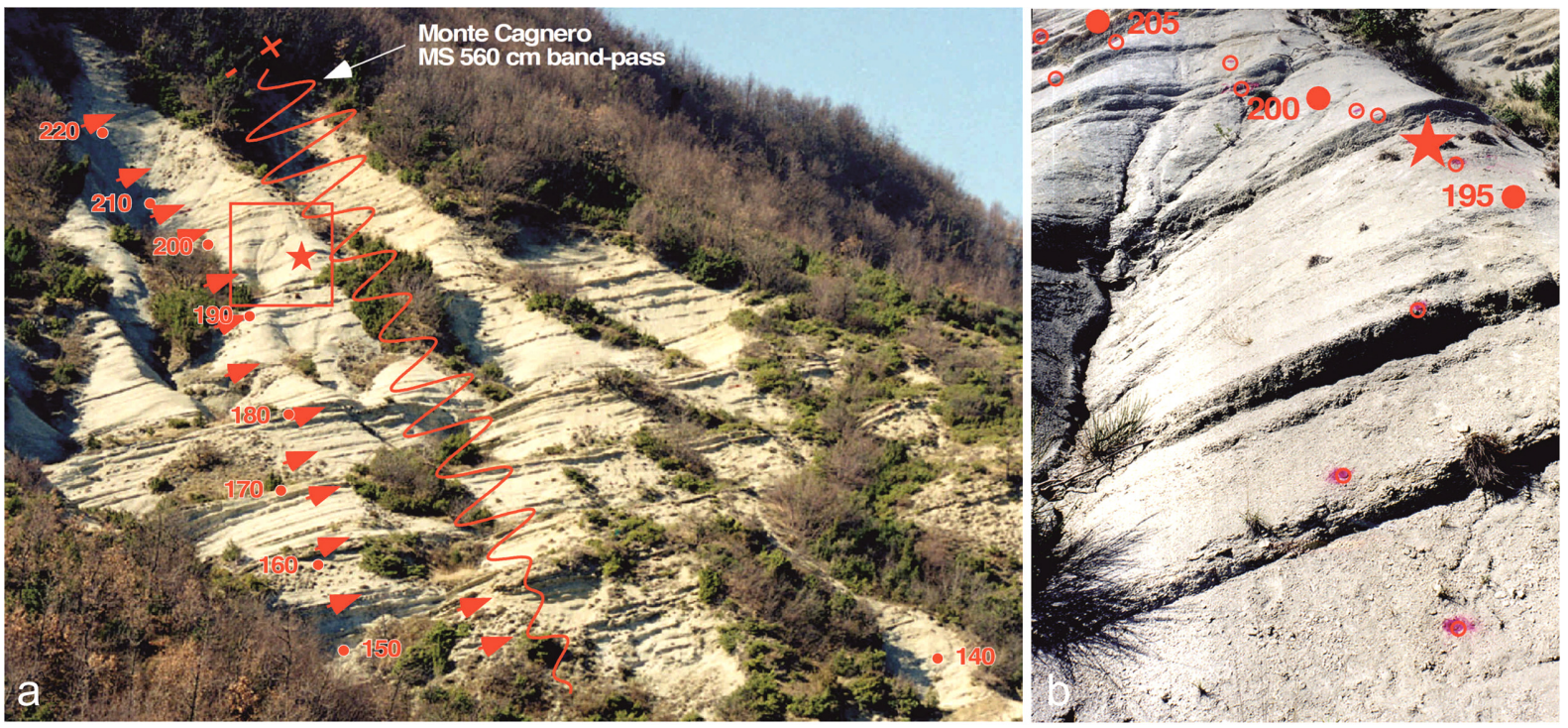

Figure 4. (a) Panoramic view of the Monte Cagnero section with superimposed band-pass curve representing the long eccentricity cycle, and arrows indicating corresponding limestone layers bundles; (b) Location of the Rupelian/Chattian boundary at meter level 197, as indicated by the star. 
C10n. Contrary to Van Simaeys et al. (2004), these results indicate that the $\mathrm{HCO}$ of $C$. cubensis is a robust bioevent for the $\mathrm{O} 4 / \mathrm{O} 5$ zonal boundary and correlates to Chron C10n, consistent with many other deep-sea sections.

King and Wade (2017) documented contrasting results in the Pacific Ocean, with the abrupt termination of $C$. cubensis close to the top of Subchron C10n.1n at ODP Site 1237 and two peaks in abundance of this species recorded just before its demise in the lower part of Chron C9n at Integrated Ocean Drilling Program (IODP) Site U1334. Moreover, King and Wade (2017) evidenced no latitudinal control on the extinction level of $C$. cubensis that was possibly controlled by ecological preferences. These findings would therefore question the legitimacy of the biostratigraphic utility of the extinction of C. cubensis as a reliable boundary marker for the Rupelian/Chattian boundary.

From all the above, it seems appropriate to provide a precise definition of the $\mathrm{HCO}$ of C. cubensis. We regard the $\mathrm{HCO}$ of an index species as the biohorizon that, on the basis of discrete changes in the abundance record, marks the end of the consistent (continuous and/or common) distribution of this species prior to its extinction. Our abundance record of C. cubensis from the MCA section is well suited for this purpose because it is based on high-resolution sampling and covers a long time interval ( 4.2 Myr) (Figs. 3 and 5). At MCA section, C. cubensis is consistently common in most of the samples from the base of the section up to meter level 201, with a highest value of $30.5 \%$ and an average value of $10.3 \%$ (Fig. 5). From meter level 198 , however, this species becomes consistently rare and above the meter level 202 it occasionally occurs with a very few specimens. Similar decline has been observed into the upper Oligocene of the western subtropical North Atlantic and the equatorial western tropical Pacific (Leckie et al., 1993), and at the low latitudes of Syria (Kucenjak et al., 2014).

Accordingly, we adopted the unambiguous criterion of using the consistent and continuous reduction in abundance of $C$. cubensis to less than one third of the average value of the abundance of this species (counted on at least 300 specimens and the average value should be not less than 3\%) as threshold value to define its HCO. Following this, the $\mathrm{HCO}$ of $C$. cubensis, is constrained in between the upper half of Chron C10n and the lower part of Chron C9n, where its abundance decreases from $19 \%$ to $3.6 \%$ (Fig. 5). We placed the HCO of C. cubensis at meter level 197 in the lower part of Chron C9n (Fig. 5). Interestingly, although with different percentage abundances, similar records have been reported from the southern Spain (up to $22 \%$ with an average value of $\sim 3.5 \%$; Alegret et al., 2008), the North Adriatic (up to $19.5 \%$ with an average value of $\sim 5 \%$; Kucenjak et al., 2014), and the south-east (up to $14 \%$ with an average value of $\sim 5 \%$ ) and equatorial Pacific Ocean (up to $13 \%$ with an average value of $\sim 4 \%$; King and Wade, 2017).

More importantly, as mentioned above, the abundance and size distribution of P. opima-nana plexus specimens at MCA closely mirrors that recognized at Site U1334. This provides evidence that the Top occurrence of C. cubensis at Site U1334 and the HCO of C. cubensis at MCA are likely the same bioevent, which is well constrained in the lower part of Chron C9n. This also shows that there are no substantial differences in extinction horizon of this species and strongly supports the reliability of the HCO of C. cubensis as the global criterion for the Rupelian/Chattian boundary.

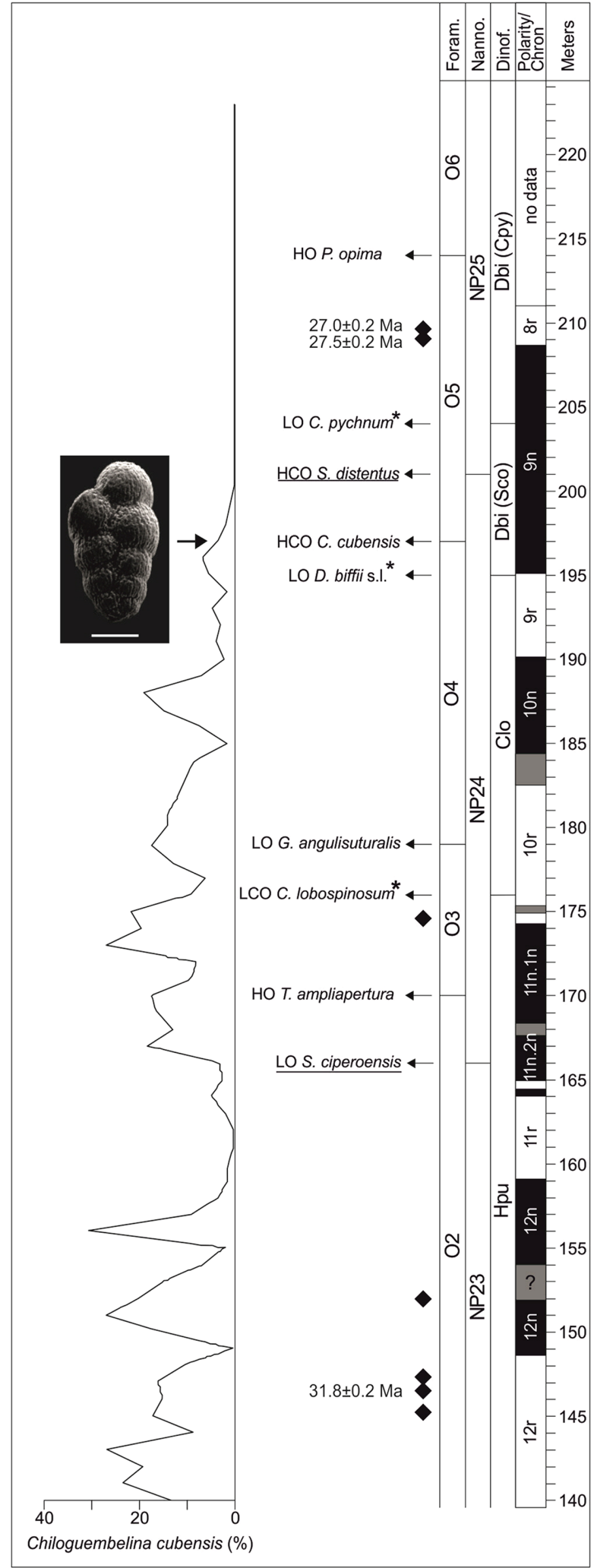

Figure 5. Abundance record of the planktonic foraminifer Chiloguembelina cubensis at the Monte Cagnero section through counting at least 300 specimens of planktonic foraminifera from the fraction larger than $63 \mu \mathrm{m}$. The highest common occurrence (HCO) of this species, which marks the base of Zone 05 of Wade et al. (2011), occurs at meter level 197. Magnetobiostratigraphy, biozonal markers, and Ar/Ar ages from volcaniclastic biotite as in Figure 4. Scale bar $50 \mu m$. 


\section{Benthic foraminifera}

The benthic foraminiferal analyses were performed on the fraction greater than $63 \mu \mathrm{m}$ of 34 selected samples among those used for the planktonic foraminiferal investigation (Fig. 2). The benthic foraminiferal assemblages of the MCA section are highly diverse and dominated by calcareous-hyaline taxa, indicating deposition well above the calcite compensation depth. The occurrence of benthic foraminiferal paleobathymetric index taxa (e.g., Bulimina truncana, previously reported as Bulimina alazanensis, Bulimina jarvisi, Cibicidoides mexicanus, Cibicidoides mundulus, Eggerella bradyi, Globocassidulina subglobosa, Hansenisca soldanii, Hanzawaia ammophila, Heterolepa bradyi, Karreriella bradyi, Oridorsalis umbonatus, Planulina costata, Planulina renzi, Pullenia bulloides, and Pullenia quinqueloba) was evaluated (e.g., Van Morkhoven et al., 1986; Katz et al., 2003). The plankton/benthos ratio ( $>95 \%$ ), the presence of paleobathymetric diagnostic taxa and the low percentages of agglutinans constrain the deposition of the MCA section to a well oxygenated, stable, bathyal environment, characterized by a depth very likely ranging between 500 and $1000 \mathrm{~m}$ (upper-middle bathyal) or somewhat deeper of $1000 \mathrm{~m}$ (upper part of lower bathyal) following the paleobathymetric assignment of van Morkhoven et al. (1986) and Katz et al. (2003), respectively.

\section{Calcareous nannofossils}

The calcareous nannofossil analysis is based on 85 samples that were collected at an average sampling resolution of $\sim 1 \mathrm{~m}$ corresponding to $\sim 75 \mathrm{kyr}$ (Fig. 2). Light microscope techniques at 1000x magnification were used for examination of smear slides prepared using standard methods. Calcareous nannofossils assemblages are generally abundant and moderately etched and overgrown. The calcareous nannofossil zonal boundaries through NP23-NP25 are traced according to the standard zonation of Martini (1971) with slight modification for the definition of the NP24/NP25 zonal boundary, for which the HCO of Sphenolithus distentus is used here instead of its HO (Fig. 2 and Table 1). In fact, this taxon is rare and scattered in the upper part of its range (Olafsson and Villa, 1992; Maiorano and Monechi, 2006), while the final decrease in abundance enables an easy detection of the $\mathrm{HCO}$ of $S$. distentus that seems to be a more reliable biostratigraphic signal than the HO. In addition to a few standard and well-known primary events, several secondary events were recognized from the uppermost part of NP22 to NP25 Zones (Figs. 2, 3, and 5; Table 1).

\section{Dinoflagellate cysts}

Dinoflagellate cyst (dinocysts) analysis is based on 58 samples (Fig. 2) that were collected at an average sampling resolution of 1.45 m (Fig. 2) corresponding to $\sim 110 \mathrm{kyr}$ and processed using standard palynological techniques. All samples contain rich, diverse and wellpreserved palynological assemblages dominated by dinocysts and bisaccate pollen. The dinocyst zonation of Pross et al. (2010) was applied. Primary and secondary events were recognized through $\mathrm{Hpu}$ to Dbi Zones (Figs. 2, 3, and 5; Table 1). Acmes of Chiropteridium spp., Lingulodinium machaerophorum and Deflandrea spp. occur at different stratigraphic levels, with a marked increase in abundance of
Svalbardella cooksoniae between meter levels 201 and 208 (Fig. 2 and Table 1).

\section{Magnetostratigraphy}

The magnetic properties of the Scaglia Cinerea of the MCA section were described and documented in detail by Coccioni et al. (2008). The magnetostratigraphic interpretation of this section is relatively straightforward and allows the recognition of all the polarity reversals from the top of Chron $\mathrm{C} 12 \mathrm{r}$ to the base of Chron C8r, although some uncertainty remains in interpreting short polarity subzones within Chrons $\mathrm{C} 12 \mathrm{n}, \mathrm{C} 11 \mathrm{n}$, and $\mathrm{C} 9 \mathrm{n}$ and the exact reversal level of Chrons C10r-C10n (Fig. 3). The succession of Chrons C13r up to C8r at the MCA section is fairly consistent with that of the classic Gubbio section at Contessa (Fig. 6). However, the polarity reversal pattern and the relative thicknesses of the Chrons of the $\mathrm{U}-\mathrm{M}$ pelagic sections exhibit some differences with the patterns of marine magnetic anomalies across the South Atlantic and North Pacific Oceans and the ODP Sites 1218 and 1219 (equatorial Pacific) (Fig. 6). Despite these uncertainties, the GSSP for the base of the Chattian at meter level 197 undoubtedly falls within the lower part of a normal polarity zone, which we interpret as Chron C9n (Fig. 2).

\section{Chemostratigraphy}

The Oligocene stretch of the numerical strontium isotope time scale is characterized by a steep, monotonic increase of the ${ }^{87} \mathrm{Sr} /{ }^{86} \mathrm{Sr}$ from about 0.70782 at the base of the Rupelian to about 0.70828 at the top of the Chattian (Fig. 7a). From the combined data of MCA and PAC sections (Coccioni et al., 2008), a precise ${ }^{87} \mathrm{Sr} /{ }^{86} \mathrm{Sr}$ value of 0.708105 \pm 0.00001 can be given to the base of the Chattian at MCA section (Fig. 7b).

Carbon $\left(\delta^{13} \mathrm{C}\right)$ and oxygen $\left(\delta^{18} \mathrm{O}\right)$ stable isotopes were measured through the MCA section by Coccioni et al. (2008) on bulk rock samples. A sample from meter level 197, the Rupelian/Chattian boundary, records a relatively low $\delta^{13} \mathrm{C}$ value of $0.05 \%$ and a relatively low $\delta^{18} \mathrm{O}$ value of $-2.0 \%$. These isotopic minima fall within an interval of relatively low $\delta^{13} \mathrm{C}$ and $\delta^{18} \mathrm{O}$ values, which is bracketed by two intervals, centered at meter levels 192 and 206, of relatively high isotopic values, which were respectively interpreted by Coccioni et al. (2008) as the Oligocene glacial events Oi2a and Oi2b of Pekar and Miller (1996) and Miller et al. (1991), respectively (Fig. 3). Accordingly, the base of the Chattian would precede the Oi2b event, i.e., the Oligocene Glacial Maximum ("OGM") of Van Simaeys (2004), by some 500 kyr (Fig. 3).

\section{Cyclostratigraphic Analysis}

Magnetic susceptibility (MS) was measured on 1600 ground rock samples collected at 5-cm resolution from meter level 144 to meter level 224, with a Bartington MS2 dual frequency sensor on low frequency $(0.465 \mathrm{kHz})$ and $\mathrm{x} 0.1$ sensitivity, as a proxy for our cyclostratigraphic analysis. Three measurements were taken on each sample and averaged to a single value in SI magnetic susceptibility unit. We conducted spectral analyses of the MCA MS proxy series in Matlab using algorithms modified from Muller and MacDonald (2000) in agreement with Hyland et al. (2009). 
Table 1. Planktonic foraminiferal, calcareous nannofossil, and dinocyst events, and Chron boundaries, with their numerical ages for the Monte Cagnero section

\begin{tabular}{|c|c|c|c|c|c|c|c|c|c|}
\hline Biostratigraphic event and Chron & $\begin{array}{c}\text { Meter } \\
\text { level }\end{array}$ & $\begin{array}{l}\text { Martini } \\
(1971)\end{array}$ & \begin{tabular}{|c|} 
Okada and \\
Bukry \\
$(1980)$ \\
\end{tabular} & $\begin{array}{c}\text { Berggren } \\
\text { et al. } \\
(1995) \\
\end{array}$ & \begin{tabular}{|c|} 
Wade \\
et al. \\
$(2011)$ \\
\end{tabular} & $\begin{array}{l}\text { Pross } \\
\text { et al. } \\
(2010)\end{array}$ & $\begin{array}{c}\text { Gradstein et } \\
\text { al. (2012) } \\
\text { GTS age (Ma) }\end{array}$ & \begin{tabular}{|c|} 
MCA Solution 1 \\
Astrochronologi- \\
cal age (Ma)
\end{tabular} & $\begin{array}{c}\text { MCA Solution } 2 \\
\text { Astrochronologi- } \\
\text { cal age (Ma) }\end{array}$ \\
\hline Chiropteridium spp. acme & 223 & & & & & & & 25.90 & 25.49 \\
\hline HO Paragloborotalia opima & 214 & & & $\mathrm{P} 21 \mathrm{~b} / \mathrm{P} 22$ & O5/O6 & & 26.91 & 26.60 & 26.17 \\
\hline HO Wetzeliella gochtii & 213 & & & & & & & 26.71 & 26.23 \\
\hline HO Areoligera semicirculata & 209 & & & & & & & 26.97 & 26.54 \\
\hline LO Artemisiocysta cladodichotoma & 209 & & & & & & & 26.97 & 26.54 \\
\hline $\mathrm{C} 9 \mathrm{n} / \mathrm{C} 8 \mathrm{r}$ & 208.7 & & & & & & 26.41 & 26.95 & 26.53 \\
\hline End Svalbardella cooksoniae interval & 208 & & & & & & & 27.03 & 26.73 \\
\hline Chiropteridium spp. acme & 207 & & & & & & & 27.09 & 26.67 \\
\hline Deflandrea spp. acme & 204 & & & & & & & 27.32 & 26.93 \\
\hline LO Caligodinium pychnum & 204 & & & & & $\begin{array}{l}\text { Dbi (Sco)/ } \\
\text { Dbi (Cpy) }\end{array}$ & & 27.32 & 26.93 \\
\hline Lingulodinium machaerophorum acme & 202 & & & & & & & 27.46 & 27.08 \\
\hline Beginning Svalbardella cooksoniae interval & 201 & & & & & & & 27.52 & 27.12 \\
\hline HCO Sphenolithus distentus & 201 & $\begin{array}{l}\text { NP24/ } \\
\text { NP25 }\end{array}$ & $\begin{array}{l}\text { CP19a/ } \\
\text { CP19b }\end{array}$ & & & & 26.80 & 27.52 & 27.12 \\
\hline LO Distatodinium biffii s.s. & 200 & & & & & & & 27.55 & 27.15 \\
\hline $\begin{array}{l}\text { HCO Chiloguembelina cubensis } \\
\text { (Rupelian-Chattian boundary) }\end{array}$ & 197 & & & $\begin{array}{l}\mathrm{P} 21 \mathrm{a} / \\
\mathrm{P} 21 \mathrm{~b}\end{array}$ & $\mathrm{O} 4 / \mathrm{O} 5$ & & 28.10 & 27.82 & 27.41 \\
\hline HO Sphenolithus predistentus & 196 & & & & & & & 27.90 & 27.52 \\
\hline $\mathrm{C} 9 \mathrm{r} / \mathrm{C} 9 \mathrm{n}$ & 195.1 & & & & & & 27.41 & 27.94 & 27.56 \\
\hline LO Distatodinium biffii s.1. & 195 & & & & & $\begin{array}{c}\mathrm{Clo} / \mathrm{Dbi} \\
(\mathrm{Sco})\end{array}$ & & 27.96 & 27.58 \\
\hline LCO Cyclicargolithus abisectus $>12 \mu \mathrm{m}$ & 193 & & & & & & & 28.08 & 27.72 \\
\hline $\mathrm{C} 10 \mathrm{n} / \mathrm{C} 9 \mathrm{r}$ & 190.2 & & & & & & 27.83 & 28.26 & 27.88 \\
\hline Lingulodinium machaerophorum acme & 189 & & & & & & & 28.35 & 27.94 \\
\hline Chiropteridium spp. acme & 187 & & & & & & & $28 . .47$ & 28.09 \\
\hline $\mathrm{C} 10 \mathrm{r} / \mathrm{C} 10 \mathrm{n}$ & 183.5 & & & & & & 28.40 & 28.69 & 28.24 \\
\hline HO Discoaster tanii nodifer & 183 & & & & & & & 28.74 & 28.31 \\
\hline LO Ectosphaeropsis sp. & 183 & & & & & & & 28.74 & 28.31 \\
\hline Chiropteridium spp. acme & 182 & & & & & & & 28.78 & 28.36 \\
\hline LO Globigerina angulisuturalis & 179 & & & P20/P21a & $\mathrm{O} 3 / \mathrm{O} 4$ & & 29.19 & 29.00 & 28.62 \\
\hline LCO Chiropteridium lobospinosum & 176 & & & & & $\mathrm{Hpu} / \mathrm{Clo}$ & & 29.23 & 28.85 \\
\hline $\mathrm{C} 11 \mathrm{n} .1 \mathrm{n} / \mathrm{C} 10 \mathrm{r}$ & 175.2 & & & & & & 29.18 & 29.32 & 28.92 \\
\hline HO Turborotalia ampliapertura & 170 & & & $\mathrm{P} 19 / \mathrm{P} 20$ & $\mathrm{O} 2 / \mathrm{O} 3$ & & 30.28 & 29.58 & 29.18 \\
\hline HCO Helicosphaera compacta & 169 & & & & & & & 29.73 & 29.33 \\
\hline C11n.1r/C11n.1n & 168.4 & & & & & & 29.45 & 29.77 & 29.28 \\
\hline C11n.2n/C11n.1r & 167.6 & & & & & & 29.50 & 29.81 & 29.30 \\
\hline $\begin{array}{l}\text { Sphenolithus predistentus/Sphenolithus } \\
\text { distentus reversal }\end{array}$ & 167 & & & & & & & 29.85 & 29.37 \\
\hline LO Sphenolithus ciperoensis & 166 & $\begin{array}{l}\text { NP23/ } \\
\text { NP24 } \\
\end{array}$ & $\begin{array}{l}\text { CP18/ } \\
\text { CP19a } \\
\end{array}$ & & & & 29.60 & 29.88 & 29.47 \\
\hline $\mathrm{C} 11 \mathrm{r} / \mathrm{C} 11 \mathrm{n} .2 \mathrm{n}$ & 165 & & & & & & 29.99 & 29.95 & 29.54 \\
\hline LO Globigerina ciperoensis & 165 & & & & & & & 29.95 & 29.54 \\
\hline HO Subbotina angiporoides & 161.5 & & & & & & & 30.20 & 29.83 \\
\hline $\mathrm{C} 12 \mathrm{n} / \mathrm{C} 11 \mathrm{r}$ & 159.1 & & & & & & 30.59 & 30.43 & 30.03 \\
\hline HCO Helicosphaera ethologa & 157 & & & & & & & 30.58 & 30.20 \\
\hline LO Oligokolpoma galeottii & 156 & & & & & & & 30.62 & 30.27 \\
\hline HO Reticulofenestra circus & 153 & & & & & & & 31.00 & 30.63 \\
\hline $\mathrm{C} 12 \mathrm{r} / \mathrm{C} 12 \mathrm{n}$ & 148.6 & & & & & & 31.00 & 31.37 & 30.97 \\
\hline HO Sphenolithus akropodus & 147 & & & & & & & 31.48 & 31.06 \\
\hline HO Reticulofenestra umbilica & 139 & \begin{tabular}{|l|} 
NP22/ \\
NP23 \\
\end{tabular} & $\begin{array}{c}\text { CP16c/ } \\
\text { CP17 } \\
\end{array}$ & & & & 32.02 & \multicolumn{2}{|c|}{32.30} \\
\hline LO Paragloborotalia opima & 139 & & & & & & & \multicolumn{2}{|c|}{32.30} \\
\hline
\end{tabular}

The ages for the HO of Reticulofenestra umbilica and the LO of Paragloborotalia opima are after Hyland et al. (2009). 


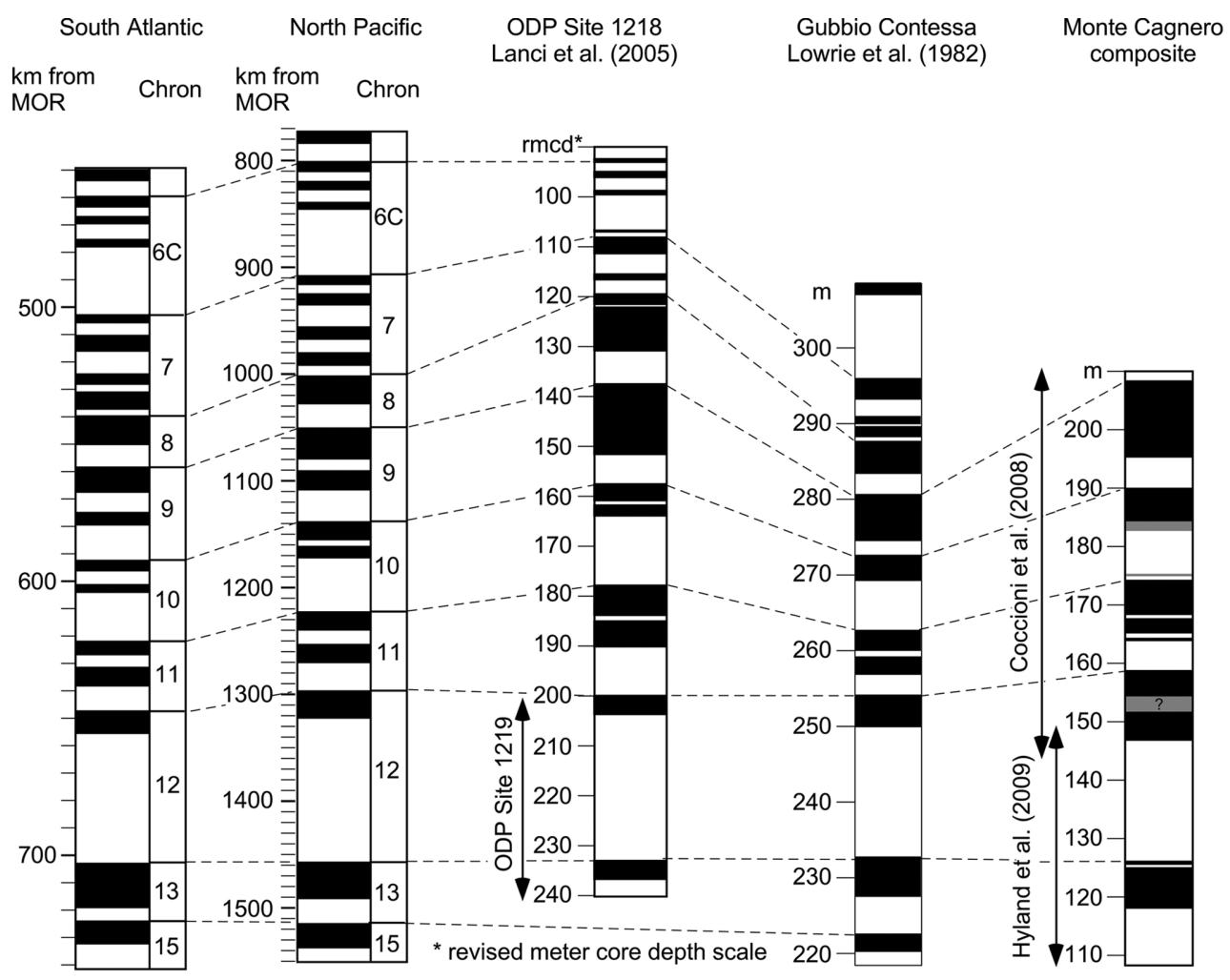

Figure 6. Correlation of the Eocene-Oligocene magnetic polarity pattern among the transects across the South Atlantic and North Pacific oceans, the cores from ODP Sites 1218 and 1219, the classic Gubbio section at Contessa, and the composite section of Monte Cagnero.

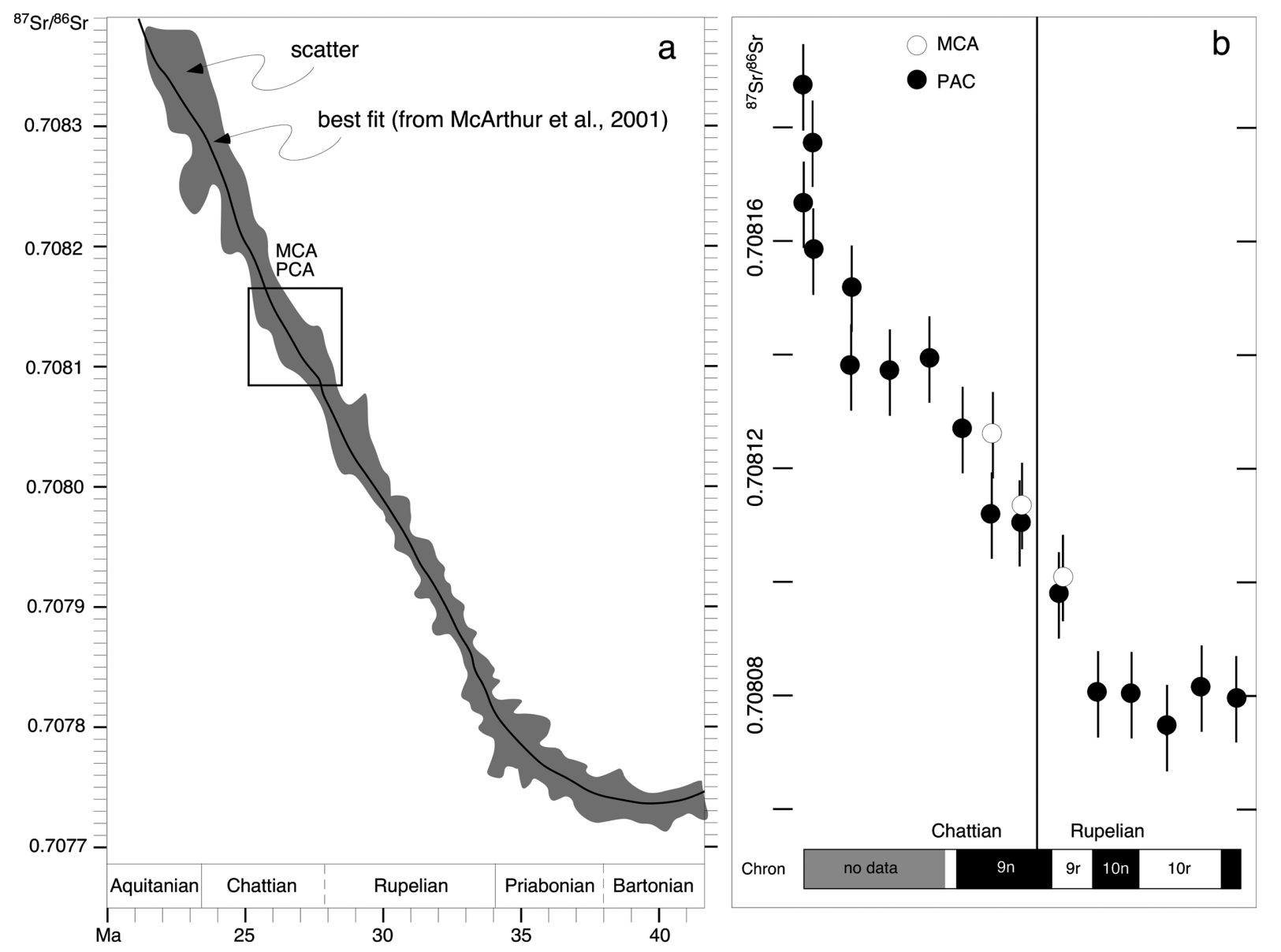

Figure 7. (a) Location of the Monte Cagnero (MCA) and Pieve d'Accinelli (PAC) sections in the strontium isotope curve of McArthur et al. (2001). (b) Strontium isotope composition across the Rupelian/Chattian boundary in the MCA and PAC sections (from Coccioni et al., 2008). 
The MS data contain an overall up-section trend toward higher values, reflecting a general increase in terrigenous influx through time, which is consistent with a general decrease in $\mathrm{CaCO}_{3}$ content (Fig. 3).

We evaluated the statistical significance of the spectral peaks by generating a $95 \%$ confidence level from a Monte Carlo noise simulation (Muller and MacDonald, 2000). Prominent, statistically significant peaks related to one another by the same ratios found between Milankovitch cycles, are assumed to represent eccentricity, obliquity (tilt), and precession, making it possible to correlate meter level to age through the calculation of an average sedimentation rate of $1.45 \mathrm{~cm} /$ kyr for the MCA section (Figs. 2 and 8a). The persistence of the spectral peaks through the stratigraphic section was evaluated through the use of an evolutionary, or sliding window, fast Fourier transforms (FFT). In this approach, a subset or window of the data is analyzed using the same FFT; the window then moves up through the time series. The window size was chosen to be $\sim 26 \mathrm{~m}$, which is large enough to enable the detection of short and long eccentricity signals given the preexisting sedimentation rate from the overall FFT power spectrum (Fig. 8b). The linearity of the signals in the evolutionary FFT plot is an indica- tion of a fairly constant sedimentation rate throughout the section. We then applied a Hilbert transform to the presumed orbital signals of precession and eccentricity, which resulted in an enveloping curve that graphically illustrates the amplitude modulation. We then applied a FFT to this enveloping curve to identify the spectral character of the amplitude modulation. A similar amplitude modulation analysis of the Laskar2004 ETP orbital parameters calculated by Laskar et al. (2004 - Laskar2004 hereafter) allowed us to compare our presumed orbital signals with the mathematically predicted orbital cycles. The frequency signals in the MCA section contained in a 17-27 kyr band (i.e., precessional cycle) do show modulations at lower frequencies compatible with Laskar2004 eccentricity cycles (Fig. 8c). Similarly, frequency signals in a $85-150 \mathrm{kyr}$ band (short eccentricity) show the expected modulation frequency of the $\sim 400 \mathrm{kyr}$ long eccentricity cycle compatible with Laskar2004 (Fig. 8d). We did not run a Hilbert transform for the presumed obliquity signal because the power spectrum appears too noisy with multiple peaks in the band of $35-45 \mathrm{kyr}$.

Astronomical tuning and ultimate dating of the MCA section were accomplished through the use of broad band-pass filtering. Variations
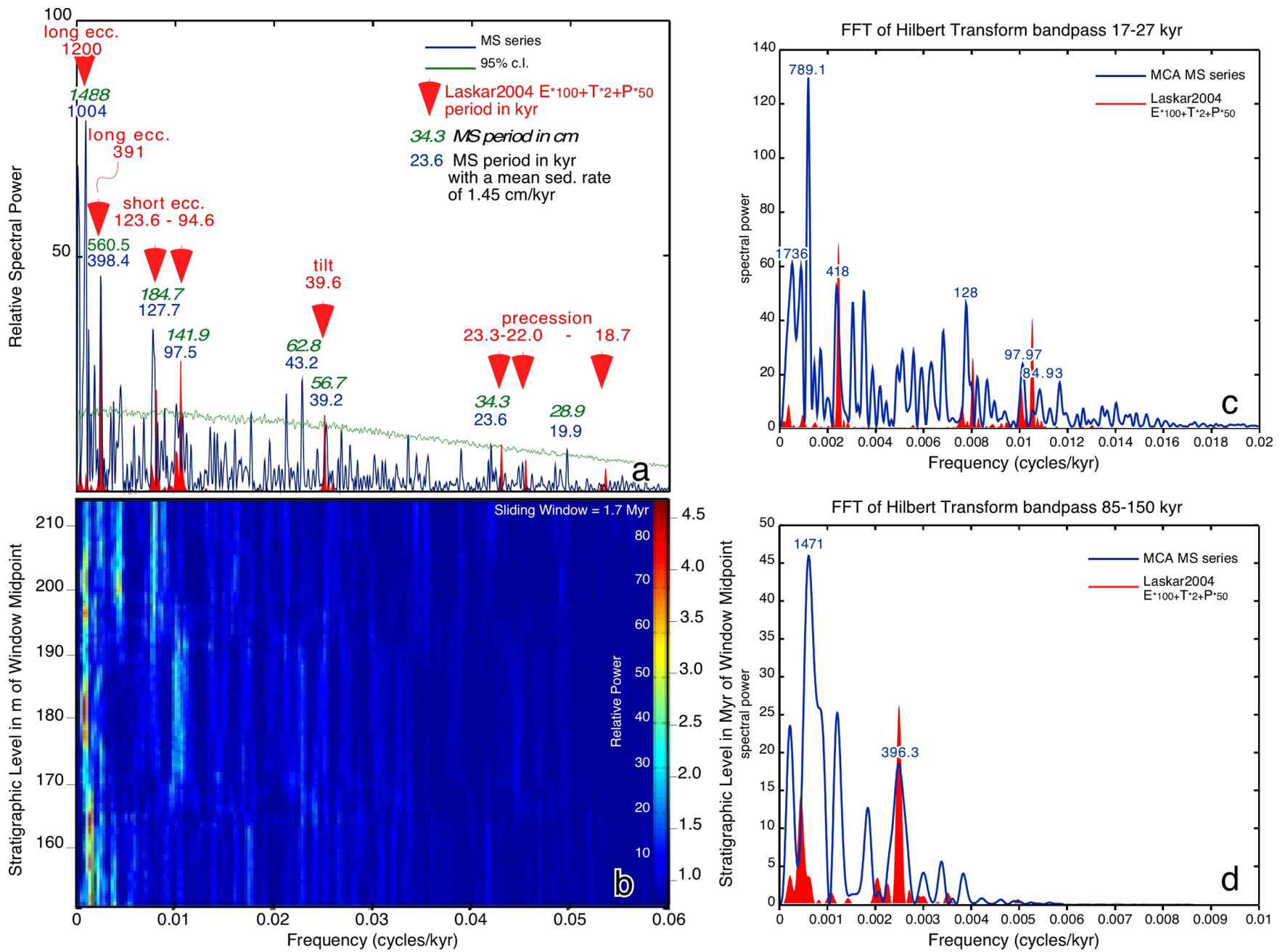

Figure 8. Spectral analysis synthesis of the magnetic susceptibility (MS) time series from the Monte Cagnero section: (a) Fast Fourier periodogram of the Monte Cagnero MS series compared to the Laskar et al. (2004) ETP series; (b) Evolutionary or Sliding Window FFT of the Monte Cagnero MS series in the time domain; (c) Hilbert transform periodogram of the precession frequency band of the Monte Cagnero MS series compared to the same frequency band from Laskar et al. (2004) ETP series; (d) Hilbert transform periodogram of the short eccentricity frequency band of the Monte Cagnero MS series compared to the same frequency band from Laskar et al. (2004) ETP series. 
in MS proxy series between 85 and $150 \mathrm{kyr}$ were isolated so as to emphasize the variance in the short eccentricity band, which, in our MCA series, includes the strongest and most consistent frequency peaks. These filtered data were then used for correlation via constrained pattern matching with the theoretical eccentricity curve of Laskar et al. (2004). The uncertainties in astronomical dating depend on (1) the astronomical solution applied; (2) the assumption of an overall constant sedimentation rate; and (3) the assumption that there is no lag between orbital forcing and its sedimentary expression (Kuiper et al., 2008). Laskar et al. (2004) estimated a maximum chrono- logical error in their calculations of $30 \mathrm{kyr}$ over the last $50 \mathrm{Myr}$. If we assume our tuning to be correct, then the combined error in astronomical solution and stratigraphical calibration on MCA section will be about \pm 50 kyr.

\section{Astronomical Tuning and Age Model}

We performed the actual tuning by correlating the maxima of a broad 4.4-7.3 $\mathrm{m}$ band pass curve of the MS proxy series with the maxima of the long eccentricity curve of Laskar2004, as shown in

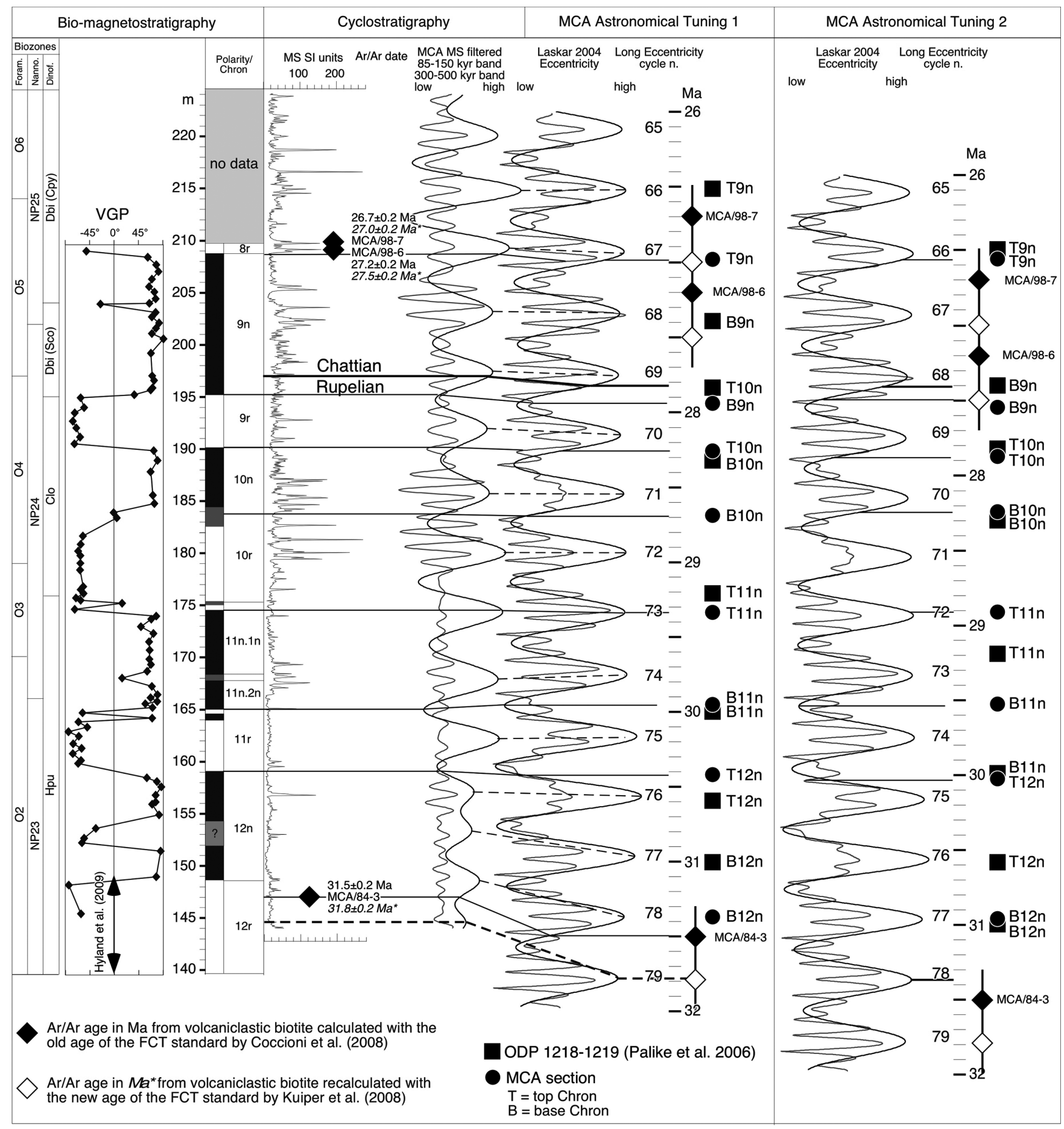

Figure 9. Two alternative astrochronological calibrations of the Monte Cagnero MS series based on the long eccentricity cycle tuned with the solution of Laskar et al. (2004). FCT: Fish Canyon Tuff. 
Figure 9. The phase relation was assumed to be such that maxima in MS (i.e., maxima in terrigenous, magnetic content) corresponded to maxima in eccentricity, which would imply a correspondence between maxima in temperature and humidity in a glacio-eustatic cyclic pattern. Once a fairly clear long and short eccentricity cyclicity has been determined through the MCA section via FFT spectral analysis of the MS proxy series, the problem arose of how to anchor our $\sim 400 \mathrm{kyr}$ (long eccentricity) cycle curve to the long eccentricity model calculated by Laskar et al. (2004), which has to be considered astrochronologically precise (to the $1 \mathrm{kyr}$ ) and accurate.

One way to perform this anchorage is to consider the radioisotopic ages obtained from volcaniclastic layers found at the bottom and the top of the MCA section (Fig. 9). Ar/Ar radioisotopic ages from two biotite-rich volcaniclastic layers located at meter level 147 (MCA/843 ) and at meter level 209.65 (MCA/98-7), which were respectively recalculated at $31.8 \mathrm{Ma}$ and 27.0 Ma by Gradstein et al. (2012) using the new age of the Fish Canyon Tuff (FCT) sanidine standard of Kuiper et al. (2008), are fairly consistent, within the $2 \sigma$ analytical error, with their astrochronologic ages resulting from the tuning 1 (Fig. 9). However, these dates, regardless of their analytical precision, bear an unquantifiable geochronological uncertainty common to all radioisotopic dates and the intrinsic method of geochronological age determination. In the case of the MCA section, a volcaniclastic biotite sample collected at $209.05 \mathrm{~m}$ (sample MCA/98-6 in Coccioni et al., 2008) yielded a ${ }^{40} \mathrm{Ar} /{ }^{39} \mathrm{Ar}$ plateau age of $27.2 \pm 0.2 \mathrm{Ma}$ (or 27.5 $\pm 0.2 \mathrm{Ma}$ using the new age of the FCT sanidine standard of Kuiper et al., 2008), which would be $500 \mathrm{kyr}$ older than the age of sample MCA/98-7 found just $60 \mathrm{~cm}$ above it. Given a mean sedimentation rate for the upper part of the Scaglia Cinerea limestone at MCA of $1.45 \mathrm{~cm} / \mathrm{kyr}$, the difference in age between these two volcaniclastic layers would be about $40 \mathrm{kyr}$ and not $500 \mathrm{kyr}$ as otherwise derived from radioisotopic dating, suggesting that one or both biotite ages bear an accuracy error. This discrepancy, along with the intrinsic accuracy uncertainty in these radioisotopic ages, constitutes a problem in the attempt of tuning the MCA section with the astrochronologic model of Laskar et al. (2004). Aware of it, we anchored the continuous $\sim 400 \mathrm{kyr}$ cycle of the interval spanning the uppermost Chron $\mathrm{C} 12 \mathrm{r}$ to the lowermost Chron C8r to the long eccentricity curve obtained by Hyland et al. (2009) continuously from the mid Chron C13r to the lower Chron $12 \mathrm{n}$, practically matching a minimum of the long eccentricity cycle found, in both intervals, at about meter level 147. The long eccentricity curve of Hyland et al. (2009) was in turn anchored to the GSSP of Massignano (mid Chron C16n to mid Chron C13n), which was tuned by Brown et al. (2009). In the MCA section, the Eocene-Oligocene boundary gave an astrochronologic age of $33.925 \pm 0.025 \mathrm{Ma}$, which closely corresponded to a maximum of the short eccentricity cycle placed in the old-side shoulder of the long eccentricity maximum n. 84 (where long eccentricity maximum $n .1$ is located, in the astrochronologic scale of Laskar et al. (2004), at $0.22 \mathrm{Ma}$ ). Moreover, Hilgen and Kuiper (2009) found consistency between the astronomically tuned ages for the Eocene-Oligocene boundary of 33.9 Ma as proposed by Brown et al. (2009) and Hyland et al. (2009), the astronomically tuned age of 33.8 Ma in the ODP core at the equatorial Pacific Site 1218 as proposed by Pälike et al. (2006), and the ${ }^{40} \mathrm{Ar} /{ }^{39} \mathrm{Ar}$ sanidine ages for the boundary as derived from the volcanic ignimbrite complex in New Mexico, and for the President White Layer (PWL) ash bed in North
America (Hilgen and Kuiper, 2009), which suggested to them that the tunings were correct at the scale of the $\sim 400 \mathrm{kyr}$ cycle. In summary, the matched minimum of the $\sim 400 \mathrm{kyr}$ cycle found at about $147 \mathrm{~m}$ in the upper Chron $\mathrm{C} 12 \mathrm{r}$ of the MCA section corresponds to the minimum of the long eccentricity cycle n. 78, whereas the maximum found at about $197 \mathrm{~m}$ would correspond to long eccentricity cycle $\mathrm{n}$. 69. On the basis of fine tuning using the short eccentricity cycle (see Astronomical Tuning 1 in Fig. 9), the Rupelian/Chattian boundary at exactly meter level 197 in the MCA section yields an astrochronologic age of $27.82 \mathrm{Ma}$.

However, Tuning 1 in Figure 9 bears some major astrochronologic inconsistencies with the tuning of the magnetic polarity sequence from Chron C13n (the Eocene/Oligocene boundary) to Chron C6An.2n (uppermost Aquitanian) performed by Pälike et al. (2006) using an apparently continuous and complete, high-resolution stable isotopes proxy series from benthic foraminifera through the composite ODP Sites 1218 and 1219. These series were also anchored to the Eocene/ Oligocene boundary in the upper part of Chron C13r, with an age of about 33.9 Ma. Yet, with the exception of the close astrochronological age match of the base and top of Chron C11n between the MCA section and ODP series, all the other Chron boundaries have age differences between 200 and $600 \mathrm{kyr}$ (see Tuning 1 in Fig. 9). Although we do not have an explanation for such a discrepancy, we tested an alternative tuning by sliding down the Laskar 2004 astrochronologic scale by one long eccentricity cycle with respect to the $\sim 400 \mathrm{kyr}$ cycle of the MCA section (see Tuning 2 in Fig. 9). By doing this, a good astrochronologic match better than $100 \mathrm{kyr}$ between the MCA and ODP series is obtained for top and bottom of Chron C9n, top and bottom of Chron C10n, and the bottom of Chron C12n, whereas a mismatch of about $300 \mathrm{kyr}$ remains for the top of $\mathrm{C} 11 \mathrm{n}$, and about 600 kyr for the bottom of Chron C11n and the top of Chron C12n. If Tuning 2 was considered less troubled than Tuning 1 (i.e., with less mismatches), it would imply that the age of the Eocene/Oligocene boundary would be that of the old-side shoulder of long eccentricity maximum cycle $n .83$ with an age of about $33.5 \mathrm{Ma}$ and not of the oldside shoulder of long eccentricity maximum cycle $n .84$ with an age of 33.9 Ma, as it was determined by Brown et al. (2009) and Hyland et al. (2009), and confirmed and corroborated by ${ }^{40} \mathrm{Ar} /{ }^{39} \mathrm{Ar}$ sanidine ages by Hilgen and Kuiper (2009). In the impossibility of solving this conundrum, in Table 1 we propose astrochronologic ages for the various biostratigraphic and paleomagnetic events recorded at the MCA section according to these two alternative tunings. It follows that the age of the Rupelian/Chattian boundary found in the lower part of Chron C9n at $197 \mathrm{~m}$ is $27.82 \mathrm{Ma}$ according to Tuning 1, and 27.41 Ma according to Tuning 2 .

\section{Historical Background on the Rupelian/Chattian Boundary and Implications for the Establishing the GSSP for the Base of the Chattian Stage at MCA}

The Rupelian and Chattian historical stages, introduced respectively by Dumont in 1849 and by Fuchs in 1894, are located in the southern North Sea basin, where the Rupelian Boom Clay Formation underlies the Chattian Voort Sand Formation (Fig. 10). The Rupelian and Chattian stratotypes have been the topic of many sedimentologi- 


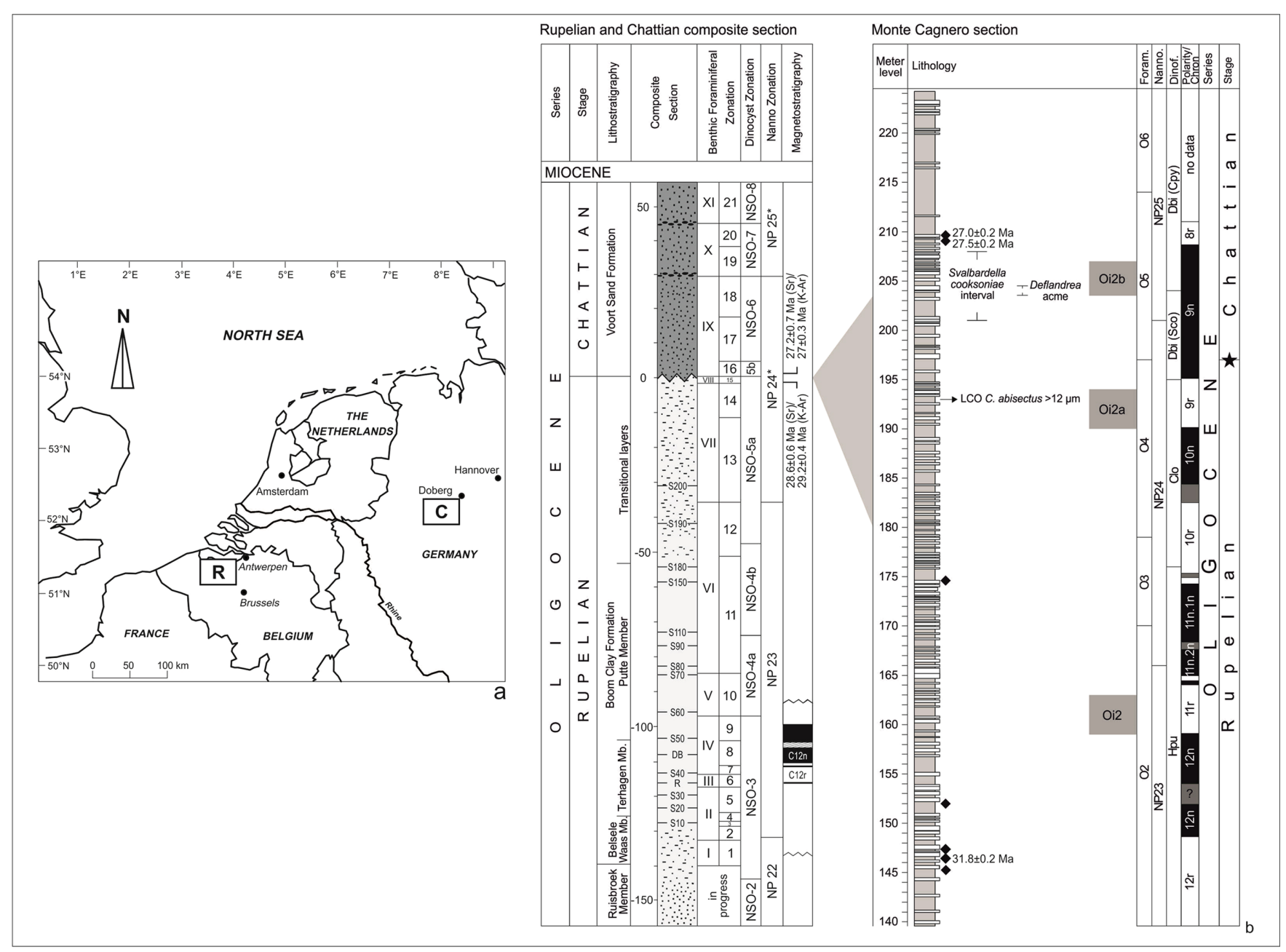

Figure 10. (a) Location of the historical Rupelian and Chattian stratotypes; (b) Correlation of the Rupelian and Chattian composite section in their type region (southern North Sea basin) (after De Man and Van Simaeys, 2004; De Man et al., 2004) with the Monte Cagnero (MCA) section in central Italy (after this work). The interval IX of the benthic foraminiferal zonation marks the range of the "Asterigerina Horizon", which defines the base of the Chattian in its original stratotype area. The star marks the location of the GSSP for the Chattian. According to the $S r$ and $\mathrm{K}$-Ar dating provided by De Man et al. (2010), in the classical area of the Rupelian/Chattian boundary the top of the Rupelian should not be older than 29 Ma and the basal Chattian should not be younger than about 27 Ma. The grey zone indicates the hiatus that spans the classic Rupelian/Chattian boundary unconformity. Following our astrochronologic time scale it should extend through $\sim 1.7$ Myr from the middle part of Chron C10r to the middle part of Chron C9n.

cal, paleontological, paleoenvironmental, paleoclimatic, cyclostratigraphic, geochemical and geochronological studies (e.g., Vandenberghe et al., 1998, 2001, 2012; Van Simaeys, 2004; De Man and Van Simaeys, 2004; De Man et al., 2004, 2010; Van Simaeys et al., 2004, 2005a, 2005b; Van Simaeys and Vandenberghe, 2006 and references therein).

The basal Chattian deposits in the North Sea basin represent a major transgressive systems tract unconformably overlying the Rupelian stratotype (Vandenberghe et al., 1998). This unconformity, which was driven by the glacio-eustatic sea-level fall linked to the Oi2b cooling event, corresponds to a stratigraphic hiatus between the top of the Rupelian and the base of the Chattian transgression and represents a third-order sequence boundary (Van Simaeys, 2004; Van Simaeys et al., 2004).

The most distinct biostratigraphic marker characterizing the base of the Chattian in the North Sea Basin is the record of the Asterigerina guerichi guerichi benthic foraminifer acme event, known as the “Asterigerina Horizon” (Fig. 10b) (De Man et al., 2004; Van Simaeys et al., 2004, 2005b; Van Simaeys and Vandenberghe, 2006).

However, accurate calibration of this bioevent and, therefore, the establishment of the age of the Rupelian-Chattian unconformity and the duration of the boundary hiatus in its type region, to the Geomagnetic Polarity Time Scale (GPTS) has been notoriously hampered by 1) the endemic nature of the North Sea Oligocene benthic foraminifera, 2) the scarcity of chronostratigraphic important calcareous plankton in the Rupelian and Chattian marginal-marine type and reference sections and 3) limited availability of reliable paleomagnetic signals and radiometric datable layers in both stratotype section and regions.

In the Boom Clay Formation, no planktonic foraminiferal zonal boundaries could be identified since some of the zonal markers were not encountered or had a peculiar range (Van Simaeys and Vandenberghe, 2006; and references therein). Some magnetostratigraphic data were provided for the Rupelian stratotype by Vandenberghe et al. (2001) (Fig. 10b).

Through the Rupelian and Chattian stratotypes, the calcareous nan- 
nofossils NP23 to NP25 Zones were recognized, adopting, however, the LO of Helicosphaera recta as the substitute marker of the base of the standard Zone NP24 and the LO of Pontosphaera enormis as the substitute marker of the base of the standard Zone NP25 (Van Simaeys et al., 2004) (Fig. 10b). In addition, a benthic foraminiferal and a dinocyst zonations have been also established (De Man et al., 2004; Van Simaeys et al., 2004, 2005b; Van Simaeys and Vandenberghe, 2006) (Fig. 10b).

A striking feature coinciding with the Rupelian-Chattian unconformity in the southern North Sea Basin is the major change in paleotemperature and paleobathymetry as testified by the benthic foraminiferal assemblages, with the shallow marine to restricted marine tropical to subtropical assemblages at the base of the Chattian strongly contrasting with the deeper marine and cold to cold-temperate upper Rupelian assemblages (De Man and Van Simaeys, 2004).

The nature and chronostratigraphic position of the Rupelian/Chattian boundary unconformity in its historical type region has been examined by De Man et al. (2010) by using biostratigraphy, strontium isotope dating of benthic foraminifera and K-Ar dating of glauconites (Fig. 10b). Although there is some inconsistency in the K-Ar glauconite dates, those from the upper part of the Boom Clay Formation and from lower part of the Voort Sand Formation suggest that the Rupelian/Chattian boundary lies between $29.2 \pm 0.4 \mathrm{Ma}$ and $27 \pm 0.3$ Ma (De Man et al., 2010). Sr and K-Ar dating indicate the top of the Rupelian to be approximately $29 \mathrm{Ma}$ and the basal Chattian about 27 Ma (Fig. 10b).

The observations of Śliwińska et al. $(2012,2014)$ demonstrated that in the North Sea basin an interval with the dinocyst Svalbardella occurs within the "Asterigerina Horizon" and is synchronous with the global Oi2b isotope cooling event as recognized in the Italian sections of Coccioni et al. (2008). Interestingly, the correlations presented by Śliwińska et al. $(2012,2014)$ also suggest that the few isolated specimens of Svalbardella recognized by Van Simaeys (2004) within the "Asterigerina Horizon" and interpreted by the same author as an effect of reworking, are on the contrary in situ. All this points to place both the Svalbardella interval and the Oi2b event within the lower Chattian deposits in the original type area and contradicts previous assumptions (Van Simaeys, 2004; Van Simaeys et al., 2004, 2005a) that both the Svalbardella interval and the Oi2b event correlates with the unconformity below the type Chattian.

From all the above, the hiatus that spans the classic Rupelian-Chattian unconformity should extend from the middle part of Chron $\mathrm{C} 10 \mathrm{r}$ to the middle part of Chron C9n (Fig. 10b) and according to our astrochronologic time scale (Figs. 3 and 9) it appears to have a duration of $\sim 1.7 \mathrm{Myr}$.

The GSSP at MCA at the HCO of the planktonic foraminifer $C$. cubensis at meter level 197 in the lower part of Chron C9n and with an astronomical age of $27.82 \mathrm{Ma}$ is therefore in agreement with the position of the historically defined Rupelian/Chattian boundary.

\section{The Criterion for the Base of the Chattian and the Sequence of Events across the Rupelian-Chat- tian Transition at MCA Section}

The best criterion for defining the GSSP of the base of the Chattian Stage is the HCO of C. cubensis. In the MCA section, this biostrati- graphic event lies at meter level 197, in the upper part of the calcareous nannofossil NP24 Zone, in the lower part of dinocyst Dbi Zone, and in the lower part of Chron C9n, i.e., about 14\% distance up from the base of this 14-m thick Chron. Meter level 197 falls $30 \mathrm{~cm}$ below the base of a prominent, 40 -cm-thick limestone bed in the middle of a recessive, 7-m-thick marly interval (Fig. 4b). This distinctive lithostratigraphic package is easily recognizable in the MCA section, and useful for recognizing the other lithostratigraphic intervals in this section, as well as in other coeval sections for regional correlation.

The location of this "golden spike" is fully consistent with the original position of the historical stratotypes (Fig. 10b). Moreover, because the HCO of C. cubensis is placed within a lithologic horizon easily recognized in the field, it also serves to locate the "golden spike" precisely in the horizon where a specific, arguably widely correlatable, biostratigraphic or magnetostratigraphic event occurs.

Our high-resolution and detailed bio-, magneto-, and chemostratigraphic study of the proposed Chattian GSSP at the MCA section, which accurately records calcareous plankton and dinoflagellate cyst biozones, magnetic reversals, seawater $\mathrm{Sr}$, and $\mathrm{C}$ and $\mathrm{O}$ isotopic variations along with its astrochronologic calibration allows accurate and prompt correlation with the most recent mammalian zonations, biostratigraphy and events of the Oligocene according to the current state of knowledge provided by Vandenberghe et al. (2012).

Furthermore, the results discussed above enable recognition of the sequence of events across the Rupelian-Chattian transition at the MCA section Figs. 2, 3, and 5). These are, in stratigraphic order from oldest (1) to youngest (6):

(1) the top of Chron C10n at meter level 190.2 that would allow correlation with marine and continental records;

(2) the oxygen isotope excursion possibly related to the Oi2a glaciation event, which falls at meter level 193 in the middle part of Chron C9r;

(3) the base of Chron C9n at meter level 195.1 that would serve as correlation with marine and continental records;

(4) the HO of the calcareous nannofossil Sphenolithus predistentus at meter level 196;

(5) the $\mathrm{HCO}$ of the calcareous nannofossil S. distentus, i.e., the base of Zone NP25, which occurs between meter levels 201 and 202 in the middle part of Chron C9n;

(6) the abundance interval of the Arctic cold-water S. cooksoniae dinocyst from meter level 201 to meter level 208, which is consistently found within Chron C9n.

\section{Summary}

The MCA section in central Italy is continuously and spectacularly exposed, well accessible, unaffected by structural deformations, rich in well-preserved planktonic foraminifera, calcareous nannofossils, and dinoflagellate cysts, and contains several biotite-rich volcaniclastic layers, some of which provided valuable radiometric dates. It fulfills all the sixteen requisites demanded by the International Commission of Stratigraphy for holding the Chattian GSSP (Table 2). The International Union of Geological Sciences has ratified the level that contains the highest common occurrence (HCO) of the planktonic foraminifer Chiloguembelina cubensis as the Global Stratotype Section and Point 
Table 2. Summary of evaluation of the Monte Cagnero section for holding the Chattian GSSP

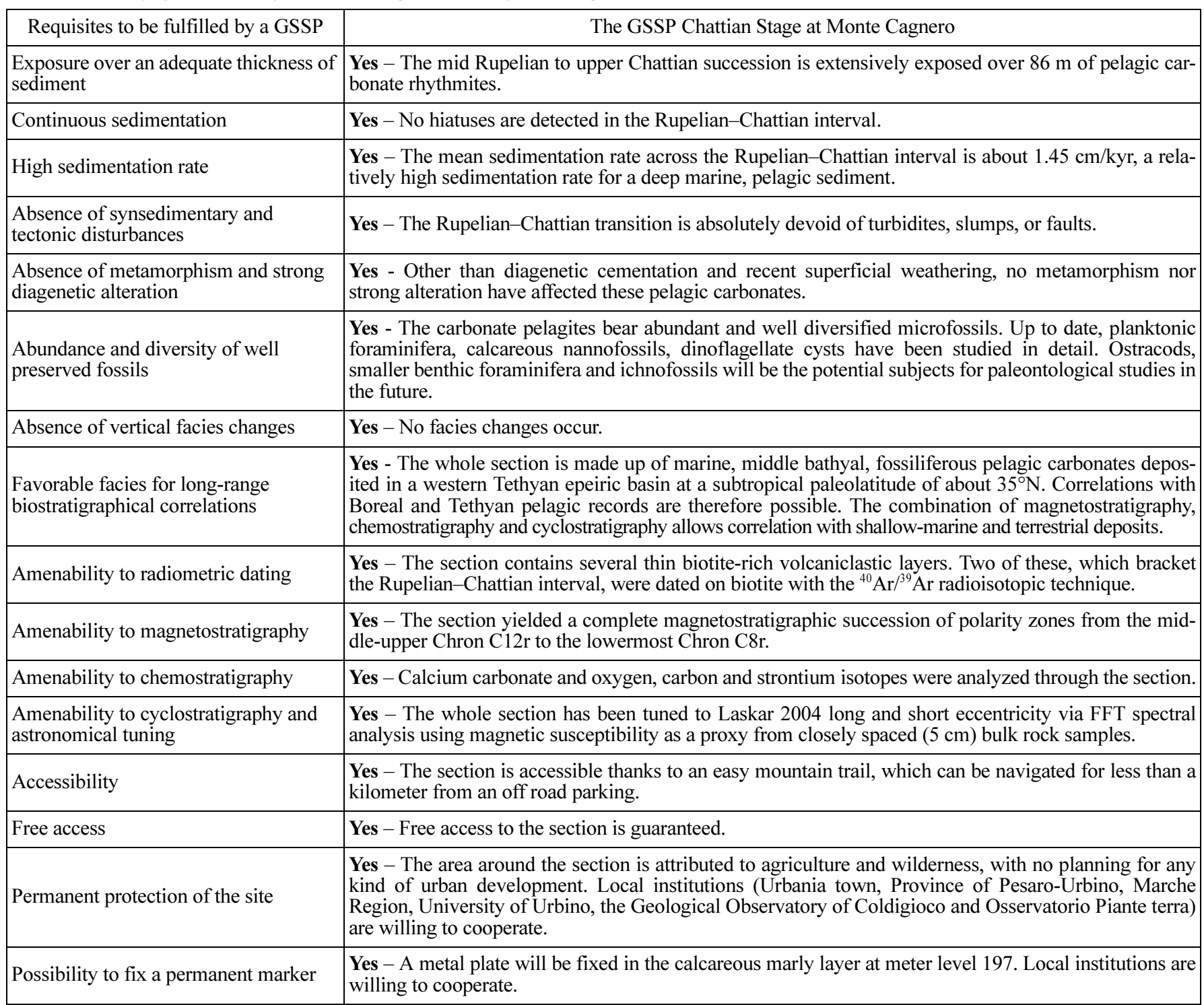

(GSSP) for the Chattian Stage, the standard chronostratigraphic unit of the upper Oligocene. This robust stratigraphic marker for the Rupelian/Chattian boundary occurs at meter level 197 of the MCA section, at the base of the planktonic foraminiferal O5 Zone and in the upper part of calcareous nannofossil NP24 Zone, in the lower part of dinocyst Dbi Zone, and in the lower Chron C9n. The location of this "golden spike" is consistent with the original position of the historical stratotypes. An astrochronologic calibration of the MCA section provides an astronomical age of $27.82 \mathrm{Ma}$ for the Chattian GSSP.

\section{Acknowledgements}

We greatly acknowledge the voting members of the International Subcommission of Paleogene Stratigraphy that provided constructive comments and suggestions, which improved the original proposal. We thank the Managing Editor Bokyun Ko, Carlo Corradini, and an anonymous reviewer for their helpful suggestions.

\section{References}

Alegret, L., Cruz, L.E., Fenero, R., Molina, E., Ortiz, S., and Thomas, E., 2008, Effects of the Oligocene climatic events on the foraminiferal record from Fuente Cladera section (Spain, western Tethys). Palaeogeography, Palaeoclimatology, Palaeoecology, v. 269, pp. 94-102.

Berggren, W.A., 1971, Tertiary boundaries. In: Funnel, B.F., and Riedel, W.R. (Eds.), The Micropalentology of the Oceans. Cambridge University Press, Cambridge, pp. 693-808.

Berggren, W.A., and Pearson, P.N., 2005, A revised tropical to subtropical Paleogene planktonic foraminiferal zonation. Journal of Foraminiferal Research, v. 35, pp. 279-298.

Berggren, W.A., Kent, D.V., Swisher, C.C., and Aubry, M.-P., 1995, A revised Cenozoic geochronology and chronostratigraphy. In: Berggren, W.A., Kent, D.V., Aubry, M.P., and Hardenbol, J. (Eds.), Geochronology, Time Scales and Global Stratigraphic Correlation. Society for Sedimentary Geology, Special Publication, v. 54, pp. 129-212.

Brown, R.E., Koeberl, C., Montanari, A., and Bice, D.M., 2009, Evidence for a change in Milankovitch forcing caused by extraterrestrial events at Massignano, Italy, Eocene-Oligocene boundary GSSP. In: Koeberl, 
C., and Montanari, A. (Eds.), The Late Eocene Earth - Hothouse, Icehouse, and Impacts. Geological Society of America, Special Paper, v. 452, pp. 1-19.

Coccioni, R., Marsili, A., Montanari, A., Bellanca, A., Neri, R., Bice, D.M., Brinkhuis, H., Church, N., Macalady, A., McDaniel, A., Deino, A., Lirer, F., Sprovieri, M., Maiorano, P., Monechi, S., Nini, C., Nocchi, M., Pross, J., Rochette, P., Sagnotti, L., Tateo, F., Touchard, Y., Van Simaeys, S., and Williams, G.L., 2008, Integrated stratigraphy of the Oligocene pelagic sequence in the Umbria-Marche basin (northeastern Apennines, Italy): a potential Global Stratotype Section and Point (GSSP) for the Rupelian/Chattian boundary. Geological Society of America Bulletin, v. 120, pp. 487-511.

De Man, E., and Van Simaeys, S., 2004, Late Oligocene Warming Event in the southern North Sea Basin: benthic Foraminifera as paleotemperature proxies. Netherlands Journal of Geosciences/Geologie en Mijnbouw, v. 83, pp. 227-239.

De Man, E., Van Simaeys, S., De Meuter, F., King, C., and Steurbaut, E., 2004, Oligocene benthic foraminiferal zonation for the southern North Sea Basin. Bulletin van het Knonklijk Belgisch Instituut voor Natuurwetenschappen - Aardwetenschappen, v. 74, pp. 177-195.

De Man, E., Van Simaeys, S., Vandenberghe, N., Harris, W.B., and Wampler, J.M., 2010, On the nature and chronostratigraphic position of the Rupelian and Chattian stratotypes in the southern North Sea Basin. Episodes, v. 33, pp. 3-13.

Dercourt, J., Ricou, L.E., and Vrielynck, B., 1993, Atlas Tethys Palaeoenvironmental Maps. Gauthier Villars, Paris, $307 \mathrm{p}$.

Dumont, M.A., 1849, Rapport sur la carte géologique du Royaume de Belgique. Bulletin de l'Académie royale de Sciences, de Lettres et des Beaux - Arts de Belgique, v. 16, pp. 251-373.

Fuchs, T., 1894, Tertiärfossilien aus den kohleführenden Miozänablagerungen der Umgebung von Krapina und Radoboj und über die Stellung der sogenannten “Aquitanischen Stufe". Mitteilungen aus dem Jahrbuche der königlich Ungarischen Geologischen Anstalt, v. 10, pp. 161-175.

Gradstein, F.M., Ogg, J.G., Schmitz, M.D., and Ogg, G.M., 2012, The Geologic Time Scale 2012. Elsevier, New York, v. 1-2, 1144 p.

Hardenbol, J., and Berggren, W.A., 1978, A new Paleogene numerical time scale. In: Cohee, G.V., Glaessner, M.F., and Hedberg, H.D. (Eds.), Contributions to the Geologic Time Scale. American Association of Petroleum Geologists Studies in Geology, v. 6, pp. 213-234.

Hess, J., Stott, L.D., Bender, M.L., Kennett, J.P., and Schilling, J.-G., 1989, The Oligocene marine microfossil record: age assessments using strontium isotopes. Paleoceanography, v. 4, pp. 655-679.

Hilgen, F.J., and Kuiper, K.F., 2009, A critical evaluation of the numerical age of the Eocene-Oligocene boundary. In: Koeberl, C., and Montanari, A. (Eds.), The late Eocene Earth - Hothouse, Icehouse, and Impacts. Geological Society of America, Special Paper, v. 452, pp. 139-148.

Hyland, E., Murphy, B., Varela, P., Marks, K., Colwell, L., Tori, F., Monechi, S., Cleaveland, L., Brinkhuis, H., van Mourik, C.A., Coccioni, R., Bice, D., and Montanari, A., 2009, Integrated stratigraphic and astrochronologic calibration of the Eocene-Oligocene transition in the Monte Cagnero section (northeastern Apennines, Italy): a potential parastratotype for the Massignano global stratotype section and point (GSSP). In: Koeberl, C., and Montanari, A. (Eds.), The Late Eocene Earth - Hothouse, Icehouse, and Impacts. Geological Society of America, Special Paper, v. 452, pp. 303-322.

Katz, M.E, Tjalsma, R.C., and Miller, K.G., 2003, Oligocene bathyal to abyssal benthic foraminifera of the Atlantic Ocean. Micropaleontology, v. 49, pp. 1-45.

King, D.J., and Wade, B.S., 2017, The extinction of Chiloguembelina cubensis in the Pacific Ocean: implications for defining the base of the Chattian (upper Oligocene). Newsletters on Stratigraphy, v. 50, pp. 311339.

Kucenjak, M.H., Premec Fucek, V., Huber, B.T., and Wade B.S., 2014, The test size and abundance variations in planktonic foraminifera Chiloguembelina cubensis and C. ototara as response to climatic events in the Oligocene. Rendiconti Online della Società Geologica Italiana, v. 31, pp. 103-104.

Kuiper, K., Deino, A., Hilgen, F., Krijgsman, W., Renne, P., and Wijbrans, J., 2008, Synchronizing rock clocks of history. Science, v. 320, pp. $500-504$.

Lanci, L., Parés, J.M., Channell, J.E.T., and Kent, D.V., 2005, Oligocene magnetostratigraphy from Equatorial Pacific sediments (ODP Sites 1218 and 1219, Leg 199). Earth and Planetary Science Letters, v. 237, pp. 617-634.

Laskar, J., Robutel, P., Joutel, F., Gastineau, M., Correia, A., and Levrard, B., 2004, A long-term numerical solution for the insolation quantities of the Earth. Astronomy and Astrophysics, v. 428, pp. 261-285.

Leckie, R.M., Farnham, C., and Schmidt, M.G., 1993, Oligocene planktonic foraminifer biostratigraphy of Hole 803D (Ontong Java Plateau) and Hole 628A (Little Bahama Bank), and comparison with the southern high latitudes. In: Berger, W.H., Kroenke, L.W., Mayer, L.A. et al. (Eds.), Proceedings of the Ocean Drilling Program: Scientific Results, v. 115. College Station, Texas, Ocean Drilling Program, pp. 113-136.

Lowrie, W., Alvarez, W., Napoleone, G., Perch-Nielsen, K., Premoli Silva, I., and Toumarkine, M., 1982, Paleogene magnetic stratigraphy in Umbrian pelagic carbonate rocks: The Contessa sections, Gubbio. Geological Society of America Bulletin, v. 93, pp. 414-432.

Luterbacher, H.P., Ali, J.R., Brinkhuis, H., Gradstein, F.M., Hooker, J., Monechi, S., Ogg, J.G., Powell, J., Röhl, U., Sanfilippo, A., and Schmitz, B., 2004, The Paleogene Period. In: Gradstein, F., Ogg, J., and Smith, A. (Eds.), A Geologic Time Scale 2004. Cambridge University Press, Cambridge, pp. 384-408.

Maiorano, P., and Monechi, S., 2006, Early to Late Oligocene calcareous nannofossil bioevents in the Mediterranean (Umbria-Marche basin, central Italy). Rivista Italiana di Paleontologia e Stratigrafia. v. 112, pp. 261-273.

Martini, E., 1971, Standard Tertiary and Quaternary Calcareous Nannoplankton Zonation. Proceedings of the Second Planktonic Conference, 1970, Rome, Tecnoscienza, v. 2, pp. 739-785.

McArthur, J.M., Howarth, R.J., and Bailey, T.R., 2001, Strontium isotope stratigraphy: LOWESS Version 3: Best fit to the marine Sr-isotope curve for 0-509 Ma and accompanying look-up table for deriving numerical age. Journal of Geology, v. 109, pp. 155-170.

Miller, K.G., Wright, J.D., and Fairbanks, R.G., 1991, Unlocking the Ice House: Oligocene-Miocene oxygen isotopes, eustasy, and margin erosion. Journal of Geophysical Research, v. 96, pp. 6829-6848.

Muller, R.A., and MacDonald, G.J., 2000, Ice Ages and Astronomical Causes: Data, Spectral Analysis and Mechanisms. Praxis Publishing Ltd., Chichester, 318 p.

Okada, H., and Bukry, D., 1980, Supplementary modification and introduction of code numbers to the low-latitude coccoliths biostratigraphic zonation (Bukry, 1973; 1975). Marine Micropaleontology, v. 5, pp. 321325.

Olafsson, G., and Villa, G., 1992, Reliability of Sphenolithus as zonal markers in Oligocene sediments from the Atlantic and Indian Ocean. Memorie di Scienze Geologiche, v. 43, pp. 261-275.

Pälike, H., Norris, R.D., Herrle, J.O., Wilson, P.A., Coxall, H.K., Lear, C.H., Shackleton, N.J., Tripati, A.K., and Wade, B.S., 2006, The heartbeat of Oligocene climate system. Science, v. 314, pp. 1894-1898.

Pekar, S., and Miller, K.G., 1996, New Jersey Oligocene "Icehouse" sequences (ODP Leg 150X) correlated with global $\delta^{18} \mathrm{O}$ and Exxon eustatic records. Geology, v. 24, pp. 567-570.

Poore, R.Z., 1984, Middle Eocene through Quaternary planktonic foraminifers from the southern Angola Basin: Deep Sea Drilling Project Leg 73. In: Hsü, K.J., LaBrecque, J.L. et al. (Eds.), Initial reports of the Deep Sea Drilling Project. U.S. Government Printing Office, Washington, D.C., v. 73, pp. 429-448.

Poore, R.Z., Tauxe, L., Percival, S.F., Jr., and LaBrecque, J.L., 1982, Late Eocene-Oligocene magnetostratigraphy and biostratigraphy at South Atlantic DSDP site 522. Geology, v. 10, pp. 508-511. 
Pross, J., Houben, A.J.P., van Simaeys, S., Williams, G.L., Kotthoff, U., Coccioni, R., Wilpshaar, M., and Brinkhuis, H., 2010, Umbria-Marche revisited: a refined magnetostratigraphic calibration of dinoflagellate cyst events for the Oligocene of the Western Tethys. Review of Palaeobotany and Palynology, v. 158, pp. 213-235.

Śliwińska, K.K., Abrahamsen, N., Beyer, C., Brünings-Hansen, T., Thomsen, E., Ulleberg, K., and Heilmann-Clausen, C., 2012, Bio- and magnetostratigraphy of Rupelian-mid Chattian deposits from the Danish land area. Review of Palaeobotany and Palynology, v. 172, pp. 48-69.

Śliwińska, K.K., Heilmann-Clausen, C., and Thomsen, E., 2014, Correlation between the type Chattian in NW Europe and the Rupelian-Chattian candidate GSSP in Italy. In: Rocha, R., Pais, J., Kullberg, J.C., and Finney, S. (Eds.), STRATI 2013. Springer, pp. 283-286.

Vandenberghe, N., Hager, H., van den Bosch, M., Verstraelen, A., Leroi, S., Sterbaut, E., Prüfert, J., and Laga, P., 2001, Stratigraphical Correlation by calibrated well logs in the Rupel Group between North Belgium, the Lower-Rhine area in Gemany ans Southern Limburg and the Achterhoek in The Netherlands. Aaardkundige Medelingen University Press Leuven, v. 11, pp. 69-84.

Vandenberghe, N., Hilgen, F.J., Speijer, R.P., Ogg, J.G., Gradstein, F.M., Hammer, O., Hollis, C.J., and Hooker, J.J., 2012, The Paleogene Period. In: Gradstein, F.M., Ogg, J.G., Schmitz, M.D., and Ogg, G.M. (Eds.), The Geologic Time Scale 2012. Elsevier, New York, v. 2, pp. 855-921.

Vandenberghe, N., Laga, P., Steurbaut, E., Hardenbol, J., and Vail, P., 1998, Tertiary sequence stratigraphy at the southern border of the North Seabasin in Belgium. In: De Graciansky, P., Hardenbol, J., Jacquin, T., and Vail, P. (Eds.), Mesozoic and Cenozoix Sequence Stratigraphy of European Basins. Society of Economic Paleontologists and Mineralogists, Special Publication, Tulsa, v. 60, pp. 119-154.

van Morkhoven, F.P.C.M., Berggren, W.A., and Edward, A.S., 1986, Cenozoic cosmopolitan deep-water benthic foraminifera. Bulletin Centre Research Exploration et Production, Elf-Aquitaine, v. 11, 421 p.

Van Simaeys, S., 2004, The Rupelian-Chattian boundary in the North Sea Basin and its calibration to the international time scale. Netherlands Journal of Geosciences, v. 83, pp. 241-248.

Van Simaeys, S., and Vandenberghe, N., 2006, Rupelian. Geologica Belgica, v. 9, pp. 95-101.

Van Simaeys, S., De Man, E., Vandenberghe, N., Brinkuis, H., and Steurbaut, E., 2004, Stratigraphic and palaeoenvironmental analysis of the Rupelian-Chattian transition in the type region: evidence from dinoflagellate cysts, Foraminifera and calcareous nannofossils. Palaeogeography, Palaeoclimatology, Palaeoecology, v. 208, pp. 31-58.

Van Simaeys, S., Brinkhuis, H., Pross, J., Williams, G.L., and Zachos, J.C., 2005a, Arctic dinoflagellate migrations mark the strongest Oligocene glaciations. Geology, v. 33, pp. 709-712.

Van Simaeys, S., Munsterman, D., and Brinkuis, H., 2005b, Oligocene dinoflagellate cyst biostratigraphy of the southern North Sea Basin. Review of Palaeobotany and Palynology, v. 134, pp. 105-128.

Wade, B.S., Berggren, W.A., and Olsson, R.K., 2007, The biostratigraphy and paleobiology of Oligocene planktonic foraminifera from the equatorial Pacific Ocean (ODP Site 1218). Marine Micropaleontology, v. 62, pp. 167-179.

Wade, B.S., Pearson, P.N., Berggren, W.A., and Pälike, H., 2011, Review and revision of Cenozoic tropical planktonic foraminiferal biostratigraphy and calibration to the geomagnetic polarity and astronomical time scale. Earth-Science Reviews, v. 104, pp. 111-142.

Wade, B.S., Poole, C.R., and Boyd, J.L., 2016, Giantism in Oligocene planktonic foraminifera Paragloborotalia opima: Morphometric constraints from the equatorial Pacific Ocean. Newsletters on Stratigraphy, v. 49, pp. 421-444.

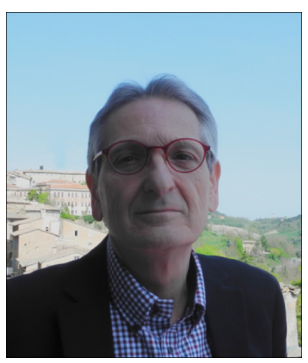

Rodolfo Coccioni is Full Professor of Paleontology at the University of Urbino in Italy. He was the President of the Italian Paleontological Society and is a voting member of the International Subcommission on Paleogene Stratigraphy. His research activity spans nearly four decades and focuses on the reconstructions of Cretaceous to Late Neogene integrated stratigraphies and on the use of middle Jurassic to Recent planktonic and small benthic foraminifera in biostratigraphy, evolution and extinction, paleoecology, paleoclimatology, paleoceanography, and applied micropaleontology. At present his research interests also include the relationships among geology and health, art, and food.

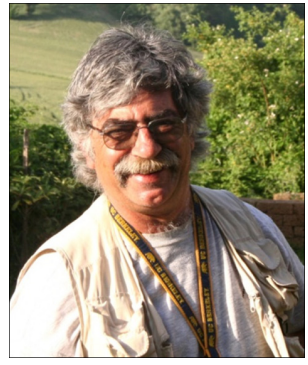

Alessandro Montanari is the Director of the Osservatorio Geologico di Coldigioco, a private educational and research center in the Marche region of Italy. As a stratigrapher and sedimentologist, his research focuses on the reconstruction of those events that have punctuated and shaped the evolution of the Earth's global environment as recoded in the Jurassic to Pliocene sedimentary succession of the northeastern Apennines, with an interdisciplinary approach integrated to geo- and astrochronology. 